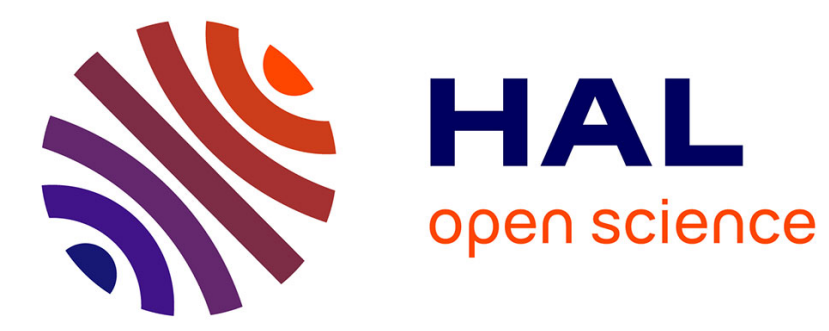

\title{
Mass-Movements in Cold and Polar Climates
}

\author{
Porsteinn Saemundsson, Costanza Morino, Susan J Conway
}

\section{To cite this version:}

Porsteinn Saemundsson, Costanza Morino, Susan J Conway. Mass-Movements in Cold and Polar Climates. Reference Module in Earth Systems and Environmental Sciences, Elsevier, 2021, 10.1016/B978-0-12-818234-5.00117-6 . hal-03356287

\section{HAL Id: hal-03356287 \\ https://hal.science/hal-03356287}

Submitted on 27 Sep 2021

HAL is a multi-disciplinary open access archive for the deposit and dissemination of scientific research documents, whether they are published or not. The documents may come from teaching and research institutions in France or abroad, or from public or private research centers.
L'archive ouverte pluridisciplinaire HAL, est destinée au dépôt et à la diffusion de documents scientifiques de niveau recherche, publiés ou non, émanant des établissements d'enseignement et de recherche français ou étrangers, des laboratoires publics ou privés. 


\section{Mass-Movements in Cold and Polar Climates}

2 Porsteinn Sæmundsson ${ }^{1,2}$

3 Costanza Morino 3

4 Susan J. Conway 4

5

6 1. Department of Geography and Tourism, University of Iceland, Askja, Sturlugata 7, 7101 Reykjavík, Iceland

8 2. Institute of Earth Sciences, University of Iceland, Askja, Sturlugata 7, 101 Reykjavik,

$9 \quad$ Iceland

10 3. Laboratoire Environnements, Dynamiques et Territoires de la Montagne UMR-

11 CNRS 5204, Université Savoie Mont Blanc, Chambéry, France

12 4. Laboratoire de Planétologie et Géodynamique de Nantes UMR-CNRS 6112,

13 Université de Nantes, France 


\section{Abstract}

Mass-movements in cold and Polar climates often involve permafrost and ice and hence these two phenomena are recurring themes throughout this chapter. We

17 consider specifically mass movements in glacial, periglacial and paraglacial settings.

18 For each environmental setting we describe the types of mass movement that have

19 been documented in the literature, describing the current research foci and remaining

20 challenges. We specifically highlight that mass-movements in cold and Polar climates

21 are particularly sensitive to climate change, because of the involvement of permafrost and ice in their triggering and dynamics and therefore we may anticipate an increasing frequency and increased hazard from these phenomena in the future in response to unprecedented rates of environmental change.

Keywords: Rapid mass movements, active-layer-detachment slides, retrogressive-

27 thaw slumps, debris flows, rock/debris falls, rock/debris slides, rock/debris avalanches, 28 deep seated gravitational slope deformation (DSGDS), slush flows, ice-flows, snow29 avalanches, permafrost, glacial environments, periglacial environments, paraglacial 30 environments, 


\section{Introduction}

Mass movement refers to the processes of downslope movement of rock, debris and soil under the influence of gravity (Crozier, 2002; Hutchinson, 1968). Mass wasting, mass movement, slope movement or slope failure are commonly used as synonyms. Another commonly used term for discrete slope movements is "landslides" (Crozier, 1989), and these movements are set apart from processes of subsidence and creep that usually lack discrete failure boundaries. Mass movements are generally divided into slow and rapid mass movements. Slow mass movements evolve over extended periods of time from months to decades or longer, such as deep-seated gravitational slope deformations (e.g., Dramis and Sorriso-Valvo, 1995). They also include phenomena like solifluction, a process that originates from the action of freezethaw cycles that induce downslope displacement in general at a rate of at most $1 \mathrm{~m} /$ year of soils in cold environments, where vegetation is lacking or sparse (e.g., Andersson, 1906; Ballantyne and Harris, 1994; Washburn, 1980). In contrast, rapid mass movements usually refer to high-magnitude, low-frequency processes that can be extremely fast moving (up to the scale of $5 \mathrm{~m} / \mathrm{s}$; Hungr, 2007).

Mass movements are classified in a number of ways, for example, according to the type of material, the type of movement, the volume of displaced material, and the extent of the material's spreading area (Cruden and Varnes, 1996; Hungr et al., 2014; Varnes, 1978). Varnes (1978) developed a classification system for slope movements, based on five possible types of movement (fall, topple, slide, spread and flow) and on

52 the type of material (rock, debris and earth). In Varnes' (1978) classification, slow 53 processes such as subsidence, creeping and solifluction are not accounted for, and 54 are considered by other authors (Sidle and Ochiai, 2006). Here, we adopt the updated 55 Varnes landslide classification from Hungr et al. (2014), where the most significant 
changes from the initial Varnes' version are: i) the use of textural classes to replace the term "earth", which has no standard definition in either geological or geotechnical material description schemes; ii) the reintroduction of "ice" as type of material, because many destructive mass movements on mountain slopes contain varying proportions of ice; iii) the introduction of slow mass movements under the movement type of "slope

61 deformation".

62 This chapter will specifically describe and discuss mass movements in cold and 63 polar environments. We divide this chapter into three sections which consider the 64 following geomorphological and environmental settings: glacial, periglacial and paraglacial. Glacial environments are those where the accumulation of ice and snow is favoured to such an extent that bodies of ice accumulate on hillslopes or even flat ground and then flow en masse (glaciers or ice caps).

Periglacial environments are those where 1) the process of ground-freezing and thawing is dominant (Tricart, 1956); 2) permafrost - defined as soil or rock with a temperature below $0^{\circ} \mathrm{C}$ continuously for $>1$ year (Dobinski, 2011; French, 2007; Muller, 1945; Péwé and Brown, 1973; Subcommittee, 1988; Washburn, 1980) - is present.

Paraglacial environments are non-glacial and landforms in this type of environments are formed during and after the deglaciation (Slaymaker, 2004; Church and Ryder, 1972). The paraglacial processes in non-glacial environments are though directly influenced by glaciation (Church and Ryder 1972).

In each section we will describe the types of mass movement that have been

77 documented in each environment, describing their general geomorphic 78 characteristics, behaviour/dynamics, and triggering factors. We will highlight 79 remaining open research questions, or key areas of active research. Finally we discuss the role of climate change in modulating the hazard posed by the mass movements in these three environments. 


\section{Rapid Mass Movements in glacial environments}

Mountainous cold and polar environments form steep-slope environments conducive to mass failures and to the presence of glaciers, hence it is not surprising that the two phenomena interact. There are four broad configurations of this interaction:

- Landslides can fall on top of glaciers without entraining a significant portion of the glacier itself so called "supra-glacial landslides".

- Landslides can fall on top of glaciers and in so doing entrain a significant portion of the glacier ice, resulting in rock-ice avalanches.

- Glaciers themselves can fail catastrophically resulting in ice avalanches. Such ice avalanches can themselves entrain debris resulting in rock-ice avalanches.

- Glaciers can advance over and remobilise landside deposits (e.g., Burki et al., 2009; Cook et al., 2013). Although glaciers could be considered as a type of mass movement, they are specifically discussed in the "Cryospheric Geomorphology" volume of this encyclopedia, and hence this remobilisation will not be detailed further in this chapter. However, this type of reworking is important in the context of supraglacial landslide deposits and will be briefly mentioned in that context.

In the following sections we will discuss first supra-glacial landslides, then ice and rock-ice avalanches.

\subsection{Supra-glacial landslides}

Spectacular examples of large-scale rock avalanches falling onto glaciers are documented in the literature, mainly from the United States (Post 1965, Shreve 1966, 
107 Dufresne et al. 2019, Crandell \& Fahnestock 1965), the Himalayas (Hewitt 1988, 108 2009a) and the New Zealand (Chinn et al. 1992). The main characteristic of such rock avalanches is the exceptionally long distances reached by the deposits over the ice surface. Several large-scale mass movements which have fallen onto glaciers during

111 recent decades have been described and an international dataset with fall height, 112 runout and volume has been developed (e.g. Schneider et al. 2011, Deline et al. 113 2015a).

114 Landslides falling onto glaciers have deposits that differ from their counterparts that 115 fall onto other terrain types due to the interaction with the ice. Most notably, their runout 116 can be a lot greater than other landslides (e.g., Evans and Clague, 1994; Pirulli, 2009; 117 Sosio et al., 2012). They tend to spread out, forming sheets of debris, which cover 118 large areas (Figure 1; e.g., Delaney and Evans, 2014). Tongue-shaped, multi-lobed 119 margins (Dufresne et al., 2019; Shreve, 1966; Shugar and Clague, 2011) and 120 longitudinal furrows/ridges/bands (e.g., Dufresne and Davies, 2009) are other 121 characteristics associated with these landslide deposits (Figure 1). A greater 122 fragmentation of the rockmass is observed compared to non-glacial slides (Delaney 123 and Evans, 2014). These observations are linked to the fact that the falling debris moves over a low-friction surface. Details on how the ice and snow incorporated in the landslide affect the physical processes which determine the landslide's motion are complex and debated (Pudasaini and Krautblatter, 2014; Schneider et al., 2011; Sosio 127 et al., 2012). It should also be noted that not all mass wasting onto glaciers causes 128 excessive runouts or distinctive deposits (e.g., Deline, 2009).

129 Similar to landslides in general, the triggers for such landslides are linked to a wide 130 variety of factors, including seismic events (Shreve, 1966) and rockwall permafrost 131 degradation (Coe et al., 2018), but of particular interest is the potential link with glacial 132 retreat (see below). 


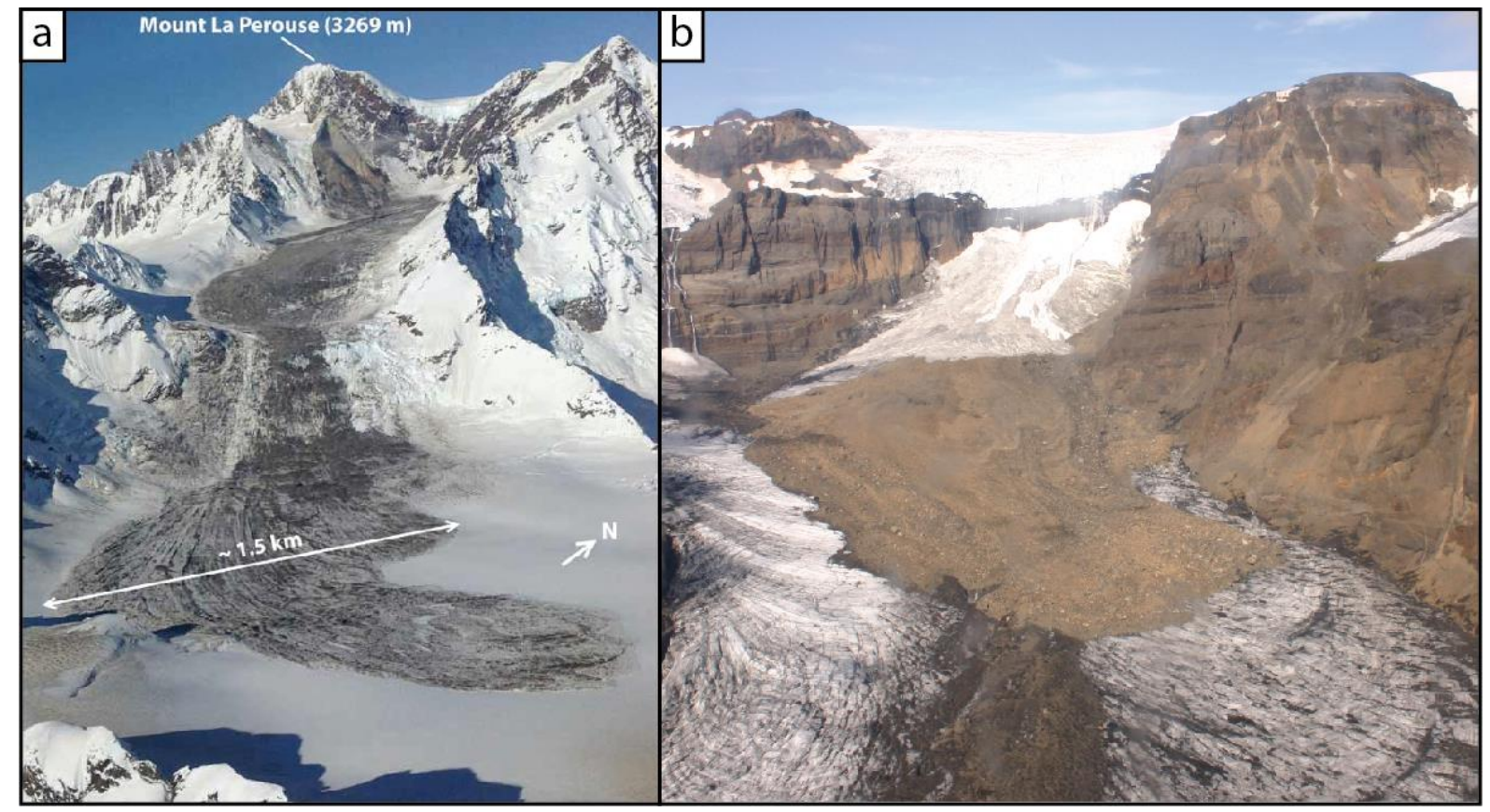

Figure 1: Examples of supraglacial rock avalanches. (a) On February 16, 2014

a rock avalanche detached from Mount La Perouse in Glacier Bay National Park, Alaska, USA. Relief from head scarp to toe is about $1770 \mathrm{~m}$. Photo taken on March 6, 2014 by Marten Geertsema. (b) The Morsárjökull rock avalanche in Iceland, which occurred on $20^{\text {th }}$ March 2007. Width of the deposit is $\sim 350 \mathrm{~m}$ and the relief from head scarp to toe is $\sim 640 \mathrm{~m}$. Photo taken in July 2007 by Matthew Roberts.

142 Snowmelt is often one of the triggers of the ground-saturation that leads to 143 landslides (e.g., Moreiras et al., 2012), but the influence of the incorporation of snow 144 itself into the body of landslides is less-well studied. Yamasaki et al. (2014) found that 145 the incorporation and propagation over deep snow alone can increase the mobility of 146 a landslide. Dufresne et al. (2019) reported that that passive sliding on snow atop of a 147 glacier caused the Lamplugh rock avalanche to slide "silently", or aseismically. This mechanism has been inferred to be the origin of many "silent" supraglacial landslides 
149 not detected by seismometers but instead in optical remote sensing (Smith et al., 150 2020).

151 The attempt to understand the dynamics of these landslides is partly driven by a 152 need to understand the long runout of these landslides, as this can pose hazard to 153 downslope communities and infrastructure, particularly if the landslide debris falls into 154 the sea or terminal lake (e.g., Dufresne et al., 2018 a,b; Hubbard et al., 2005).

155 Understanding the magnitude-frequency of this type of landslide is important for 156 understanding their role in landscape evolution at geological timescales, yet this is 157 remarkably hard to quantify as deposits are usually unrecognisable in the landscape 158 due to glacial reworking (e.g., Schleier et al., 2015). Debris that falls in the 159 accumulation zone can be hidden by snowfall then rapidly sequestered into glaciers on the order of months (e.g., Dunning et al., 2015; Smith et al., 2020). Hence, deposits that fall on the ablation zone are transported down-glacier and contribute to the glacial 162 deposits which are reworked beyond recognition at geological timescales. Some 163 success has been obtained by monitoring seismic signals (e.g., Ekstrom and Stark, 164 2013), but this only gives a snapshot of the situation at the present day. These 165 landslides are on the continuum in our understanding of the role of mass movements 166 in landscape evolution during glacial retreat (see Section 4 on mass movements in Paraglacial environments) and it is still an open question as to whether paraglacial or supraglacial mass movements play a greater role in shaping what we recognise today as the typical post-glacial landscape.

170 These landslides also play a role in conditioning the behaviour of glaciers and have 171 therefore been studied by glaciologists in order to understand glacial response to 172 changing climate and the sedimentary deposits (e.g., Reznichenko et al., 2011). 173 Debris in the ablation zone can alter glacial dynamics by shutting off ablation (e.g., 174 D'Agata and Zanutta, 2007), or accelerating it. Debris can accelerate the glacier 
175 motion (e.g., Shulmeister et al., 2009) and provoke surging behaviour (e.g., Hewitt, 176 2009a). Equally, thick isolating debris can decelerate, or stall glacial movement.

177 Supraglacial debris inputs by landslides can confound attempts to use moraines as 178 markers of glacial advances/retreats and therefore limit their use as climate markers.

179 This is because they confuse the sedimentary record via the introduction of significant 180 lags between temperature changes and recorded "events". The dynamic interplay 181 between debris and ice within the glacial system is an active area of research and the 182 role of mass movements in this interplay is yet another piece to add to the puzzle. The 183 key drivers motivating research in this field are: understanding glacial meltwater 184 generation for its contribution to sea level change, hydroelectricity generation and as a resource for potable water. Generation of glacial meltwater and sediment can also generate hazardous process-linkages and pose significant risk to infrastructure and 187 habitation.

\subsection{Ice, Rock-ice and ice-rock avalanches}

\subsubsection{Snow, ice avalanches and slushflows}

Snow and ice avalanches are a common type of rapid mass movement in cold and polar environments and are a critical driver of alpine glacial accumulation (e.g., Price et al., 2019). They take many forms because they can incorporate materials with a wide range of material properties (powder snow, sintered snow, ice, liquid water, rocks, debris, mud...) in varying proportions and can include phase changes e.g. from ice to water. From a geomorphology point of view many of these mass movements are

197 transient as they do not supply significant sediment volume. Avalanche debris cones 198 and strewn boulders are landscape elements that indicate the dominance of 
200 Sæmundsson, 2010; Jomelli and Francou, 2000; Luckman, 1992). Research into snow

201 avalanches is mainly driven by a desire to understand the risk and design engineering 202 solutions to mitigate it.

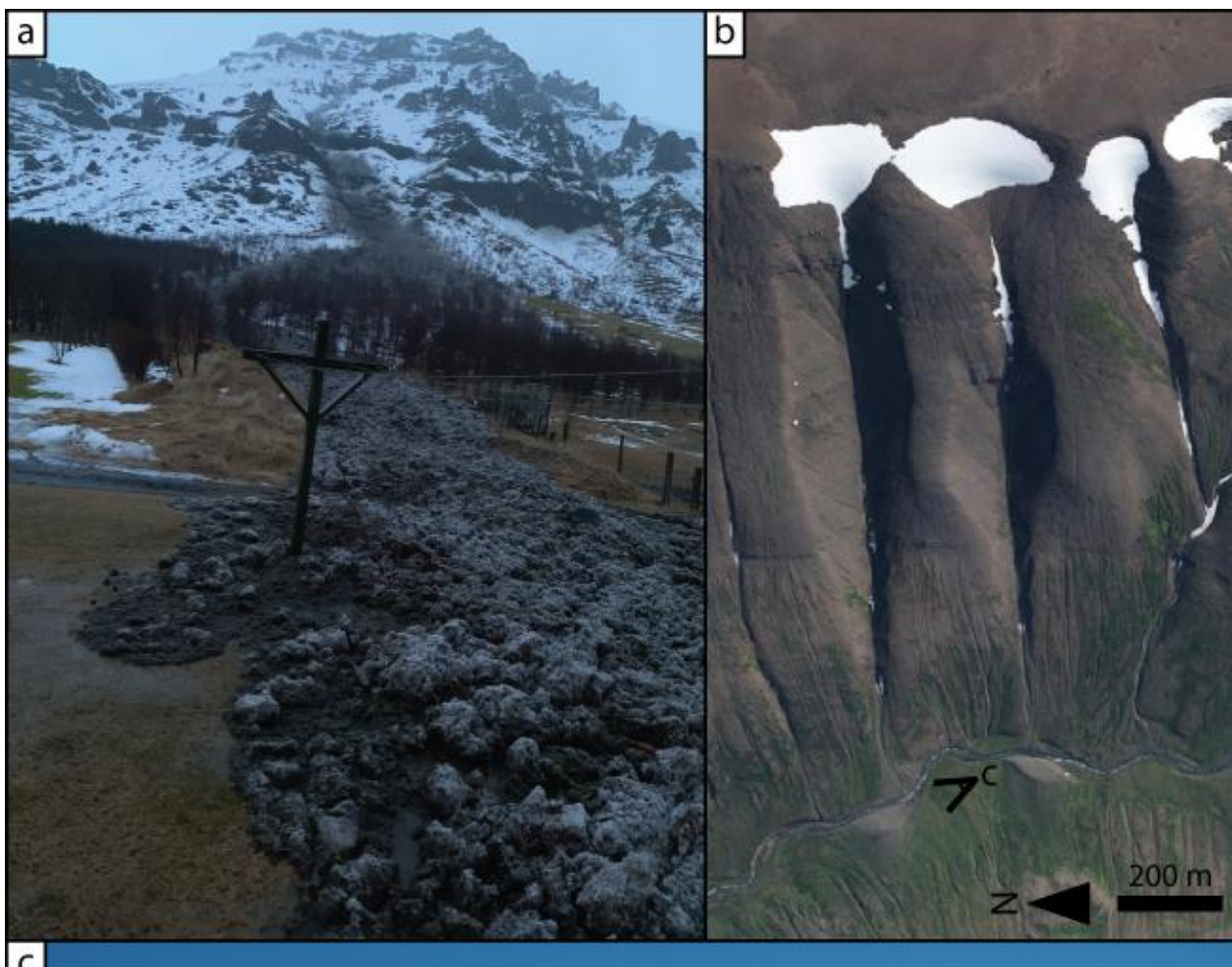

c

Figure 2: Examples of slush flow and avalanche deposits. (a) Freshly deposited slushflow from the Mt. Bleikkollubólstindur above the farm Hof in SE, Iceland. Photo 
valley, northern Iceland, which host frequent snow avalanches whose deposits are 208 found on the opposite side of the stream in the valley. The viewpoint of panel $c$ is noted on the figure. Credit Loftmyndir ehf. (c) Field view of avalanche deposits within which pebbles from the stream below are found. A person is standing atop the deposits for scale. Photo taken by porsteinn Sæmundsson 2016.

Slush flows are mass movements that behave like debris flows (described fully in 214 Section 3), but contain a significant amount of snow or ice (e.g., André, 1990; Decaulne and Sæmundsson, 2006; Elder and Kattelmann, 1993; Gude and Scherer, 1995; Hétu et al., 2017; Larocque et al., 2001; Nyberg, 1989; Pérez-Guillén et al., 2019). They are characterised by levees and lobate tongues (Figure 2a) and have a longer runout than dry avalanches. They are capable of transporting clasts up to metres in size, although some slush flows contain only snow and are usually called "slush avalanches" or "wet avalanches" (Figure 2a; e.g., Bartelt et al., 2012; Eckerstorfer and Christiansen, 2012).

221 Slush flows are triggered in a similar way to debris flows, by saturation of the sliding 222 mass by snowmelt or precipitation. There has not yet been any research that permits 223 the distinction of slush flow and debris flow deposits in the sedimentary record meaning their impact on the landscape at geologic timescales is broadly unknown. Slush flows are generally studied alongside snow avalanches or debris flows and form part of a spectrum of processes that can pose hazard to populations and infrastructure 227 in steep mountainous environments.

\subsubsection{Ice, ice-rock and rock-ice avalanches}

Mass movements in glacial areas can originate from the glaciers themselves, the

231 hillslopes, or both. Once initiated these mass movements can further interact with 
232 downslope debris, snow, ice or rock causing complex events that can be hard to 233 classify uniquely (e.g., Petrakov et al., 2008).

234 There have been three recent well-reported cases where large portions of glaciers 235 detached to form rapid mass movements (Evans et al., 2009a; Falaschi et al., 2019; 236 Gilbert et al., 2018; Kääb et al., 2018; Tian et al., 2017). For example, the collapse of 237 two nearby glaciers in the Aru range in Tibet was widely reported in the media because 238 of the remarkable visibility in satellite images (Figure 3a). However, these mass 239 movements leave very little geomorphological evidence in the landscape, because 240 their main constituent is ice which is rapidly ablated in the relatively warm locations 241 where the deposits are laid down. Hence, the frequency of such failures in the geologic 242 record is unknown. The limitation to a handful of present-day cases means that, 243 although these types of failure pose considerable risk, there are many open questions 244 as to how they are triggered. 


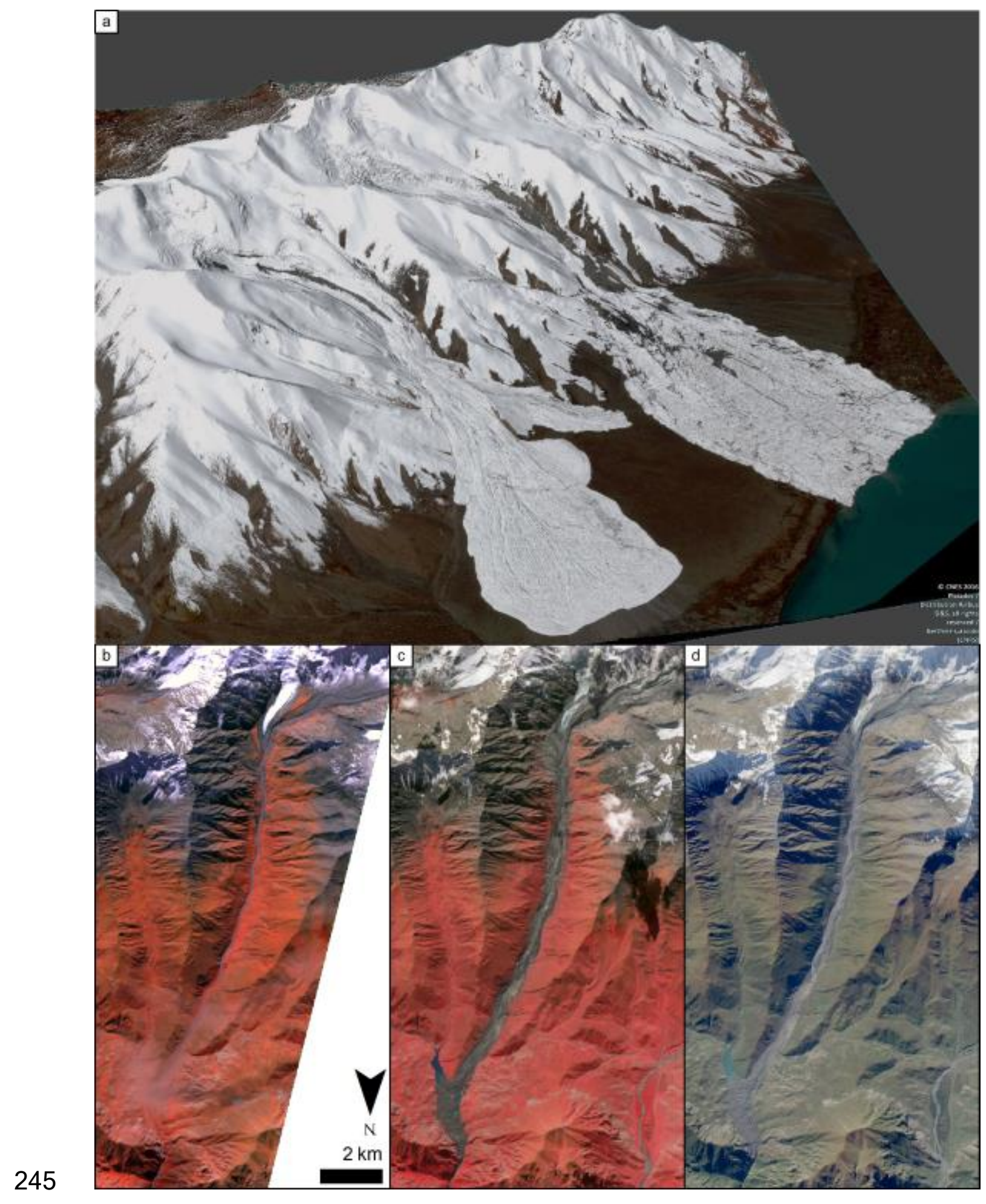

246 Figure 3: (a) Pléiades 3D rendering of the two glacier collapses in the Aru

247 Mountains, Tibet with kind permission of Etienne Berthier at the CNRS. The fan in the 248 foreground is $\sim 2 \mathrm{~km}$ across. Image credit CNES Pléiades, Airbus Defence and Space. 249 (b, $c$ and d) Mt. Kazbek in Southern Russia before and after a hanging glacier 250 collapsed from the slope of Mt. Dzhimarai-Khokh onto the Kolka Glacier which 
triggered an avalanche of ice and debris that went over the Maili Glacier terminus then slid more than $24 \mathrm{~km}$ burying villages in North Ossetia on 20th September 2002. (b, c) False-colour images from the Advanced Spaceborne Thermal Emission and Reflection Radiometer (ASTER) aboard NASA's Terra satellite. The deep reds show vegetated land surfaces, grey areas are bare rock, and white shows ice-cover. (d) True colour image from the Advanced Land Imager instrument on the EO-1 spacecraft. Images available from https://earthobservatory.nasa.gov

Landscape change does occur where glaciers and rock detach together, or rock avalanches impact and incorporate glaciers or rock glaciers (Evans et al., 2009b; Haeberli et al., 2004; Schneider et al., 2011). Triggering of these large, complex events has been attributed to thermal perturbations from both climate and geothermal origins (Huggel, 2009; Huggel et al., 2012). These events occur on the flanks of volcanoes as well as in in uplifted mountain areas. They have no specific geomorphic signature and can display the attributes generally associated with rock avalanches (Figure 3b-d), debris avalanches, debris flows and supraglacial landslides, with their defining characteristic being their large mobility. The large-scale of these events and their mobility means they are both rare, but can be extremely hazardous (Evans et al., 2009b; Iribarren Anacona et al., 2015). The deposits of ancient rock-ice avalanches are reported in the literature, but only when the role of the ice is thought to have played

271 a minimal effect on the resulting geomorphology (Robinson et al., 2014). It is unclear 272 how important such large mass movements are in long-term landscape evolution, 273 because their sedimentary signal is hard to detangle from other mass movements with 274 which they share morphologic properties. The main research challenge lies in 275 dissecting the dominant processes within the evolution of the mass movement to understand the mobility and potential hazard of such flows. Predicting where and when 
277 such huge movements might occur remains the major challenge, as it does for rock 278 avalanches in general.

279

\section{Mass Movements in periglacial environments}

Periglacial environments are sensitive to rapid changes in local climate, snow cover, 282 topography, incoming radiation, ground and soil characteristics, which influence the 283 variability of ground thermal regimes at local scale (e.g., Harris and Pedersen, 1998; 284 Harris et al., 2009; Thomas et al., 2009; Hasler et al., 2015). As average temperatures 285 continue to rise, permafrost and permafrost ice are expected to degrade (Biskaborn et al., 2019; Blunden and Arndt, 2020; Christiansen et al., 2010; Gisnås et al., 2017; Harris et al., 2009; Romanovsky et al., 2010; Slater and Lawrence, 2013), particularly at high latitudes, where average yearly temperatures are increasing at faster rates than global averages (Alexeev and Jackson, 2013; Blunden and Arndt, 2020; MassonDelmotte et al., 2006; Screen et al., 2012).

In the last decades, mass movements have been studied in relation to degrading permafrost conditions (Ashastina et al., 2017; Blais-Stevens et al., 2015; Fischer et al., 2006; Gruber and Haeberli, 2007; Haeberli et al., 2017a; Huscroft et al., 2003; Patton et al., 2019a; Ravanel et al., 2017). Mass movements are particularly common under periglacial conditions, as freeze-thaw weathering causes deterioration of rock, sediments and soils (e.g., Dobinski, 2011; Harris et al., 2001). Frost action promotes mechanical fragmentation of rocks (Matsuoka and Murton, 2008; Prick, 2003), with resulting loose material available for transport (Van Vliet-Lanoë and Fox, 2018).

299 Degrading-permafrost conditions reduce slope stability, as reaching $-1.5^{\circ} \mathrm{C}-0{ }^{\circ} \mathrm{C}$ or 300 melting temperatures causes reduction in ground shear strength, loss of ice/rock interlocking, increase in the hydraulic permeability, and ice segregation (Davies et al., 
2001; Draebing et al., 2017; Draebing and Krautblatter, 2019; Gruber and Haeberli, 303 2007; Krautblatter et al., 2013a; Matsuoka and Murton, 2008; Murton et al., 2006).

304 Different types of mass movements can occur in terrains affected by permafrost, 305 which in high-latitude lowland permafrost regions is classified into zones based on its 306 geographic extent and continuity. Permafrost is defined continuous where frozen 307 ground is present at $90-100 \%$ localities, while it is defined discontinuous where units 308 of frozen ground (50-90\%) are separated by unfrozen areas. Sporadic and isolated 309 permafrost is restricted to limited areas, covering respectively $10-50 \%$ and $0-10 \%$ of 310 the terrain considered as permafrost (e.g., Black, 1954; French, 2007; Péwé, 1983).

311 Permafrost is also present at lower latitudes at high elevation, it is called mountain 312 permafrost, and it is characterised by an extreme spatial variability (Gruber and 313 Haeberli, 2007; Haeberli et al., 2011; Péwé, 1983; Stearns, 1966). Mass movements 314 in periglacial environments can be distinctive of a particular class of permafrost or 315 ubiquitous in various permafrost terrains, and we will specifically discuss: active-layer316 detachment slides, retrogressive-thaw slumps, debris flows, rock/debris falls, 317 rock/debris slides, rock/debris avalanches.

\subsection{Active-layer-detachment slides}

Active-layer-detachment slides are localised slope failures (Figure 4) that are confined to the permafrost active layer in continuous and discontinuous ice-rich 322 permafrost terrains (Leibman, 1995; Lewkowicz, 1990; Lewkowicz et al., 1992; 323 Lewkowicz and Harris, 2005a,b). They fall in the suite of landforms resulting from the process of thawing of ice-rich permafrost or melting of massive ground ice called thermokarst (French, 2007; Kokelj and Jorgenson, 2013). They occur due to a 
strengths, due to rapid thawing of ice lenses at the base of the active layer or in the upper part of permafrost in fine-grained soils with low hydraulic conductivity (French, 2007; Lamoureux and Lafrenière, 2009; Lewkowicz, 2007). The movements generally involve shallow ( $\sim 1 \mathrm{~m}$ deep) failures over a thin shear zone or shear plane on very lowangled slopes (Kokelj and Jorgenson, 2013; Lewkowicz and Harris, 2005a). Few direct

332 observations exist of in-action active-layer-detachment slides, and they develop over 333 a period of minutes to several days by a single almost instantaneous sliding movement 334 or by progressive movements of a few metres per hour, reaching runout distances of 335 up to several hundred metres (Lewkowicz, 2007; Lewkowicz and Harris, 2005a). 336 Active-layer-detachment slides usually occur in clusters (Balser et al., 2009; Couture and Riopel, 2008; Lamoureux and Lafrenière, 2009), generally after warm summers, rapid spring thaw, high snowmelt, prolonged summer precipitation, or forest or tundra fires (Gooseff et al., 2009; Lamoureux and Lafrenière, 2009). Active-layer-detachment 340 slides can enhance slope sediment and solute yields in stream systems (Lamoureux 341 and Lafrenière, 2009; Lewkowicz, 2007; Lewkowicz and Kokelj, 2002), impact the 342 patterns of tundra vegetation communities (e.g., Cannone et al., 2010; Frost et al., 343 2018; Verdonen et al., 2020) and mobilise carbon sequestered in shallow permafrost 344 (e.g., Abbott et al., 2015; Beamish et al., 2014; Turetsky et al., 2019; Woods et al., 2011). An increase in active-layer-detachment slides has been observed also in the western Antarctic Peninsula region, where permafrost has reached degrading 347 temperatures $\left(-0.4\right.$ to $-3.1^{\circ} \mathrm{C}$; because the area has been affected by the greatest 348 degree of warming in the past 50 years (Bockheim et al., 2013; Guglielmin, 2012; 349 Vieira et al., 2008). Research is particularly focussed on the role these mass 350 movements have in releasing carbon contributing to the positive feedback mechanism of the warming climate releasing carbon trapped in continuous permafrost, which goes on to exacerbate future warming and so on. Although areas with continuous permafrost 
are sparsely inhabited, these mass movements can pose risk to infrastructure (e.g.

354 Behnia and Blias-Stevens 2018), but also to archaeological investigations (Walls et al. 2020).

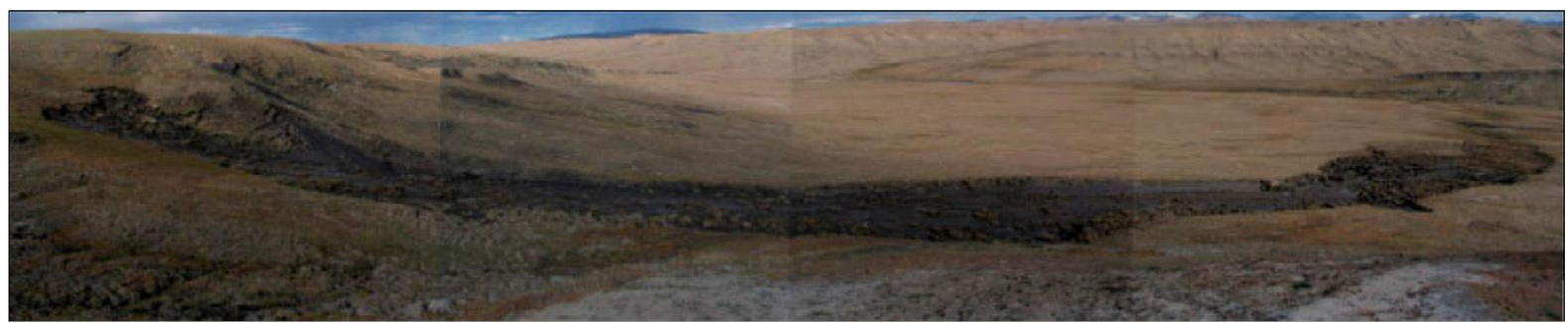

Figure 4 - Active-layer detachment slide (perimeter marked with white dashed line),

Fosheim Peninsula, Ellesmere Island, Nunavut, Canada. Modified after Lewkowicz, 2007.

\subsection{Retrogressive-thaw slumps}

Retrogressive-thaw slumps are semi-circular depressions resulting from thawing of ice-rich permafrost terrains (Burn and Friele, 1989; French, 2007; Lantuit and Pollard, 2008). They occur where ice-rich permafrost is exposed to thaw, and are generally triggered by wave action along coasts, undercutting erosion of banks along streams or lakes, or active-layer-detachment slides (Lantuit and Pollard, 2008; Patton et al., 2019b). Thaw slumps cannot be classified as "rapid movements" - they can develop over decades (Lacelle et al., 2010) - but phenomena like falls or flows can transport thawed material from the slump headwall as secondary movements (Lantuit et al., 2012; Murton, 2001). They can cover vast areas, from 0.05 up to $0.8 \mathrm{~km}^{2}$, as in the case of the Batagaika mega-thaw-slump (Figure 5), which in the last thirty years has increased its size by three times, reaching an area of $0.78 \mathrm{~km}^{2}$ in 2018 (Vadakkedath et al., 2020). Thaw slumps expose ground ice to thaw, modify the landscape, and can erode and transport thawed material to lakes, valley-bottoms or coastal zones (Kokelj et al., 2015; Lafrenière and Lamoureux, 2019; Lantuit et al., 2012; Murton et al., 2017). 
376 Retrogressive thaw slumps are showing an accelerated activity due to global warming

377 in continuous and discontinuous permafrost terrains, from western Canadian Arctic to

378 Siberia (e.g., Ashastina et al., 2017; Jones et al., 2019; Segal et al., 2016). Thousands

379 of retrogressive thaw slumps have formed in the last 30 years due to extreme 380 temperatures in High Arctic (Banks, Island, Canada), and are modelled to rise to over 381 10,000 per decade by 2075 (Lewkowicz and Way, 2019). Hence, similarly to active382 layer detachment slides current research focuses on the impact climate change is 383 having on these mass movements.

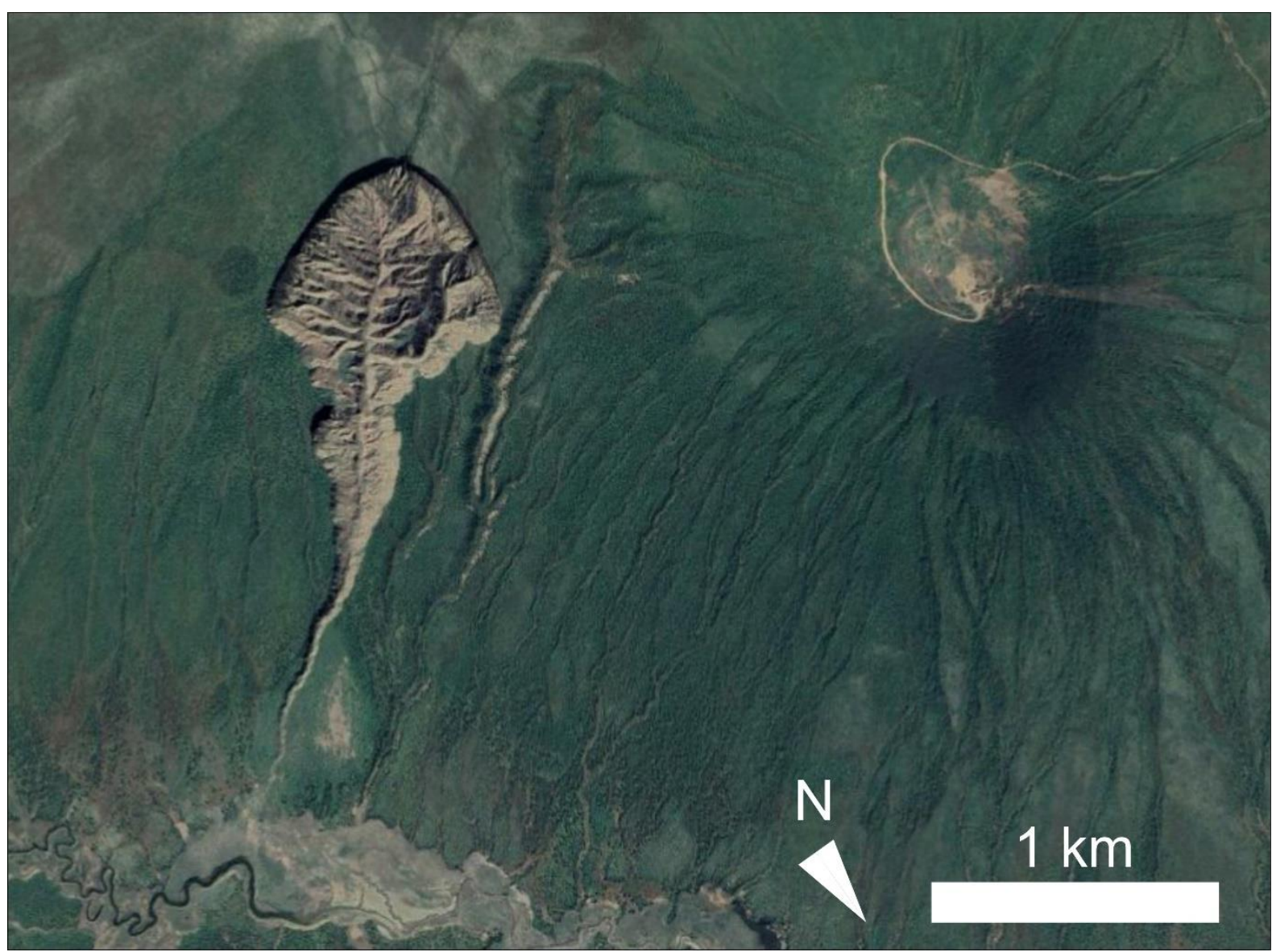

Figure 5 - The Batagaika mega-thaw slump in the Chersky Range area, Sakha Republic, Russia. CNES/Airbus Image from Google Earth, 6th October 2019. 
Debris flows are rapid, downslope flows of poorly sorted debris mixed with water 390 (e.g., Iverson, 1997), and are common on the slopes of periglacial environments, 391 including in the European Alps to Iceland (Figure 6), from the Tibetan Plateau to 392 Antarctica (Decaulne and Sæmundsson, 2006b; Morino et al. 2019; Cannone et al., 393 2006; Oliva and Ruiz-Fernández, 2015; Sattler et al., 2011; Yu et al., 2020). Debris 394 flows can travel over long distances and transport large amounts of material at great 395 speed (Zimmermann and Haeberli, 1992). They are characterised by a central 396 channel, the construction of levees on one or both sides of channel, and a terminal 397 depositional lobe or lobes (e.g., Costa, 1984). Steep slopes, loose materials and wet 398 conditions are favourable for the occurrence of debris flows (Lewin and Warburton, 399 1994). This combination of factors is extremely common in periglacial mountain 400 environments, where climatic warming during the 19th and 20th centuries has 401 indirectly increased the frequency of debris flows (Decaulne and Sæmundsson, 402 2006b; Haeberli et al., 1990; Rebetez et al., 1997; Zimmermann, 1990; Zimmermann 403 and Haeberli, 1992). This increased frequency is not directly linked to the thaw of 404 perennially frozen debris in the source areas (i.e., meltwater producing a source of 405 fluid), but it has been shown that there is a link between the initiation zones and the 406 thickening of the active layer as a reaction to the increase in atmospheric temperatures 407 (Sattler et al., 2011). This has also been observed where the interface between frozen 408 and unfrozen ground seems to control the depth of movement in debris flows (Huscroft 409 et al., 2003). Active-layer failures may result from increased concentration of water 410 above the permafrost table, generating debris flows and mass failures (Kummert et al., 411 2018; Lugon and Stoffel, 2010; Marcer et al., 2020), particularly in formerly frozen 412 sediment mantled slopes (Davies et al., 2001; Fischer et al., 2013; Haeberli, 2013). 413 Recently deglaciated terrains have an abundance of debris often perched in unstable 
414 positions that are particularly susceptible to remobilisation by debris flows (Ballantyne

415 2002).

416 Debris flows often pose hazard to human habitation and infrastructure and the main

417 challenge lies in developing tools to effectively predict where and when they will be

418 triggered in addition to understanding their runout. On one hand this requires, a deeper

419 understanding of the physical mechanisms where significant effort is being put into

420 focussed monitoring and developing sophisticated physics-based models. And on the

421 other hand it also requires the development simple yet effective tools to enable public

422 authorities and other stakeholders to mitigate the hazard posed by debris flows.

423

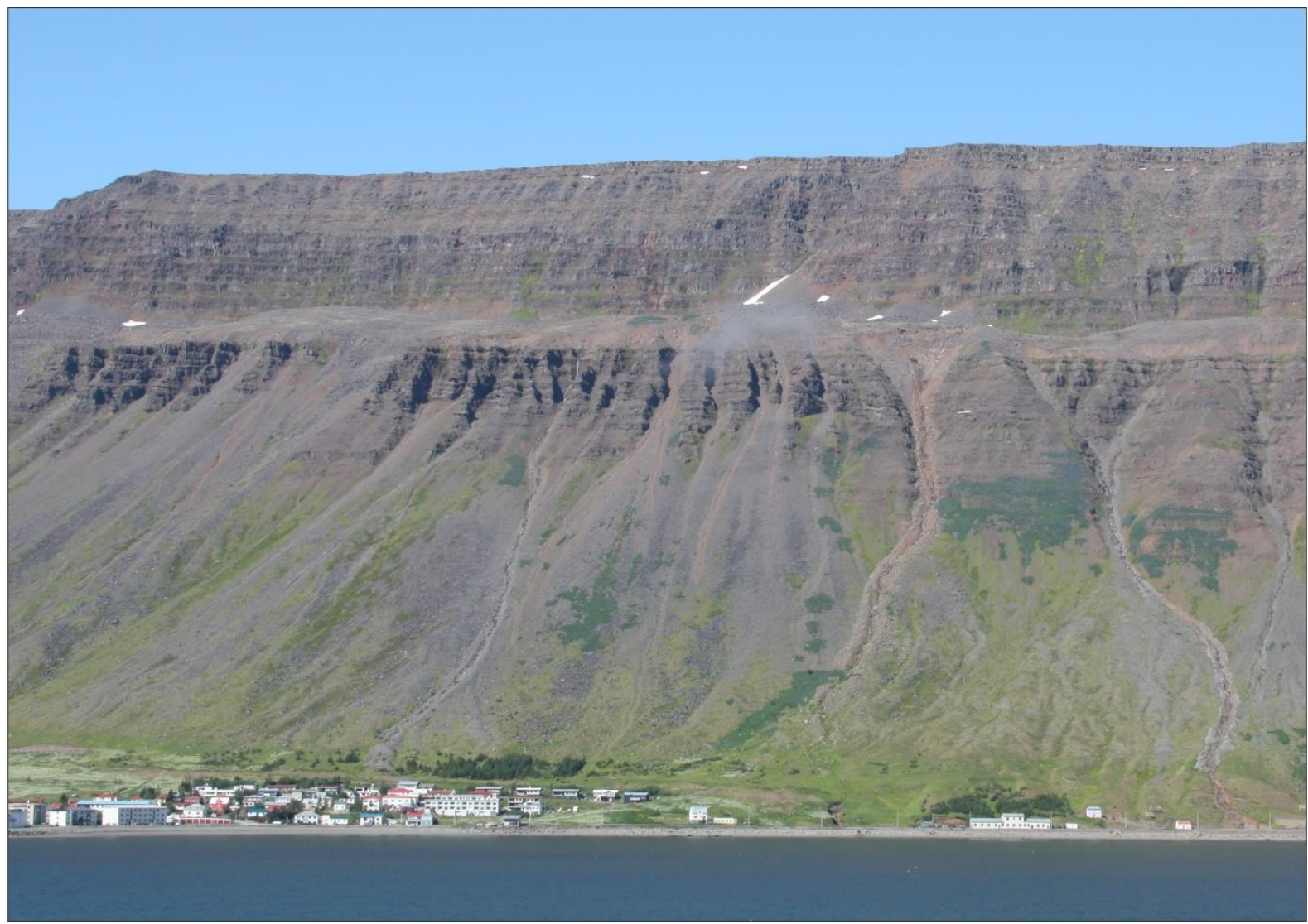

425 Figure 6 - The debris flows above in the Gleidarhjalli slope above the town of

426 Ísafjörður, Westfjords, Iceland (Decaulne and Sæmundsson, 2006b; Morino et al. 427 2019). 
429

430

431

432

433

434

435

436

437

438

439

440

441

442

443

444

445

446

447

448

449

450

451

452

\subsection{Rock/debris falls}

Rock/debris falls are mass movements on steep slopes (Fig. 7a), rock/debris slides (Fig. 7b) are mass movements that occur along discrete surfaces, and rock/debris avalanches are large-volume $\left(>1 \mathrm{M} \mathrm{m}^{3}\right)$ mass movements that cause fragmentation during rapid transport (Fig. 7c) (Cruden and Varnes, 1996; Hungr et al., 2014). These phenomena are frequent in mountain glacial and periglacial environments, usually in paraglacial settings where glacial over-deepening, stress-release fracturing after removal of glacial ice (Ballantyne, 2002; McColl and Davies, 2013), glacial debuttressing (Blikra et al., 2006; Cossart et al., 2014), degrading permafrost (Clague et al., 2012a; Deline et al., 2015a; Fischer et al., 2006; Gruber and Haeberli, 2007; Krautblatter et al., 2013b; Magnin et al., 2020; Morino et al., 2019; Sæmundsson et al., 2018), and cooling-warming cycles (Draebing, 2020) can all act to destabilise rock walls and debris source areas. These factors can induce changes in the stress field and expose previously insulated surfaces to altered mechanical and thermal erosion (Draebing et al., 2017; Haeberli, 1997; Jia et al., 2015; Krautblatter et al., 2013b; Wegmann et al., 1998), which can consequently favour mass wasting processes. The increase in temperatures in the last decades due to climate change has resulted in increased activity of such rock/debris falls, slides and avalanches; a correlation between exceptional heatwaves and rockfalls (Fig. 7a) has been established (Huggel et al., 2012; Ravanel et al., 2017; Ravanel and Deline, 2008). When permafrost degrades, physical changes also occur in the rock mass and in loose deposits (Allen and Huggel, 2013; Draebing et al., 2017; Gruber and Haeberli, 2007; Harris et al., 2009; Ravanel et al., 2017). After permafrost thaw, the shear strength of rock/debris significantly reduces with warming (minimum factor of safety is between $-1.5^{\circ} \mathrm{C}$ and 
$4530^{\circ} \mathrm{C}$ ) (Davies et al., 2001). Ice segregation and volume expansion subsequent to 454 increased temperatures can lead to failures (Gruber and Haeberli, 2007). Elevated 455 water pressure and reduced frictional strength can result from meltwater or ground456 water flow in previously frozen masses (Harris, 2005). Ice-rich permafrost occurs in 457 loose-deposits landforms such as rock glaciers, ice-cored moraines and talus slopes 458 (Dramis et al., 1995; Isaksen et al., 2000; Kenner et al., 2017; Lukas et al., 2005; 459 Monnier and Kinnard, 2015), and its degradation can cause a reduction in 460 cementation, which can lead to the occurrence of falls, slides (Fig. 7b) or avalanches 461 (Fig. 7c; Dramis et al., 1995). Rock and debris falls, slides and avalanches directly 462 attributed to this mechanism have been reported from numerous locations in cold 463 climates around the globe, including Alaska, Canada, European Alps, Greenland. 464 Himalaya, New Zealand, Norway, Russia (Deline, 2009; Evans et al., 2009a,b,c; 465 Fischer and Huggel, 2008; Frauenfelder et al., 2018; Gruber et al., 2017; Huggel et al., 466 2012, 2005; Magnin et al., 2019; Patton et al., 2019a; Sosio et al., 2008; Svennevig et 467 al., 2019). Much current research is focussed on mitigating the risk from such events 468 and is reliant on understanding and modelling the influence of increasing temperature 469 on the state of the permafrost, the influence of the associated hydrology which finally 470 leads to the destabilisation of rock mass. 


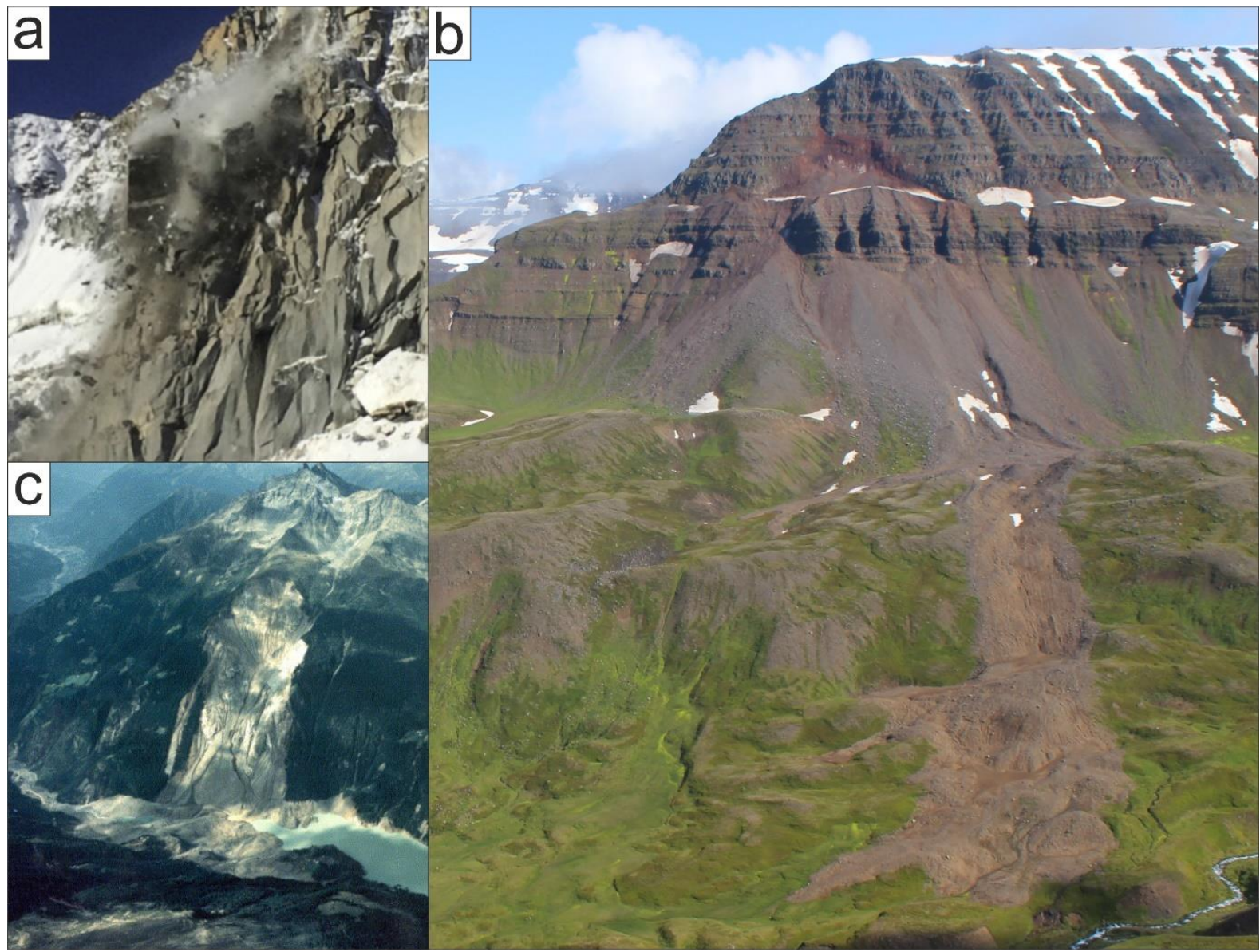

473 Figure 7 - Rapid mass movements caused by permafrost degradation. $a$. The Tour

474 Ronde rock fall of 27th August 2015, Mont Blanc Massif, France (modified after

475 Ravanel et al., 2017); b. The Móafellshyrna debris slide of $20^{\text {th }}$ September 2012,

476 Tröllaskagi peninsula, Iceland (Sæmundsson et al. 2018, Morino et al. 2019); c. The

477 Val Pola rock avalanche of $28^{\text {th }}$ July 1987, Central Alps, Italy (modified after Crosta et 478 al., 2004).

\section{Rapid Mass Movements in Paraglacial Environments}

481 Paraglacial environments represent the relatively rapid adjustment from deglaciated 482 landscape to non-glacial conditions (Ballantyne 2002). A wide range of subaerial 483 processes are active in these environments which can be active over different 484 timescales and lead to different rates of landscape change (evolution). Many of these 
processes are intimately associated with periglacial environments, already described

486 in Section 3. Periglacial conditions usually only persist for a relatively short period after

487 deglaciation, and here we focus on (large scale) Mass Movements that are not 488 necessarily related to periglacial environmental conditions, yet occur in a paraglacial 489 setting.

490 Massive rock slope failures are as frequent or more frequent in glaciated basins 491 than in equivalent ice-free mountainous terrain (McSaveney 2002, Geertsema et al. 492 2006, Hewitt 2009a Deline et al. 2015a). Complex interactions between several factors 493 can affect the occurrence of mass movements according to Pacione (1999); inherent 494 factors (e.g. lithology, rock structure, slope form, topographic relief), preparatory 495 factors (e.g. weathering, de-buttressing, climate change), triggering factors (e.g. 496 earthquake, rainstorm) and factors that may affect mobility (e.g. glacial surface) 497 (Agliardi et al. 2012, Deline et al. 2015b). According to Ballantyne (2002) the response 498 of a rock slope to glacier down wasting has been reported to result in large rock 499 avalanches, large-scale, progressive and slow rock mass deformation, and frequent 500 rock fall events. Slope steepening caused by glacial erosion and unloading or de501 buttressing due to glacial retreat often leads to rock slope failures (Agliardi et al. 2012, 502 Holm et al. 2004, Lane et al., 2017, Stoffel \& Huggel 2012). Thermal and mechanical 503 alteration can result from cycles of ice loading and unloading and exposition of rock to 504 new thermal regimes due to the glacier retreat (Cody et al., 2020; Coquin et al., 2015; 505 Evans and Clague, 1994; Grämiger et al., 2017; McColl, 2012; McColl and Draebing, 506 2019; Mercier et al., 2017; Wegmann et al., 1998). Finally, permafrost fluctuations 507 throughout the Holocene is likely a first order control on past and modern rock slope 508 failures (Hilger et al., 2021). 


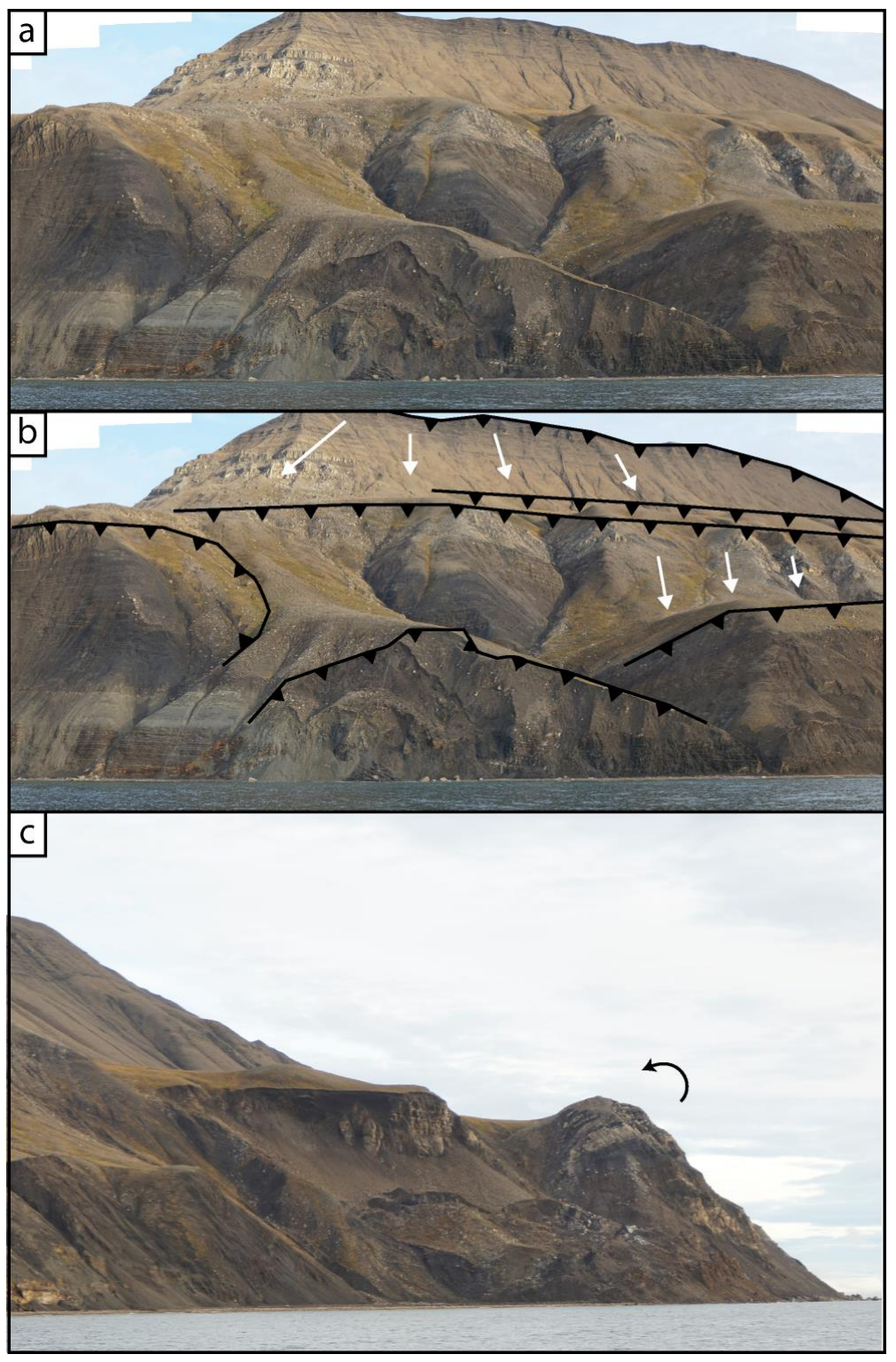

510 Figure 8 A Deep seated gravitational slope deformation at Forkastningsfjellet in

511 Spitsbergen documented by Kuhn et al. (2019, 2021). (a) Unannotated view towards

512 the blocks that are sliding downslope. (b) Annotated view showing the location of the

513 main sliding surfaces that define the different blocks with white arrows indicating

514 displacement directions. (c) Side-on view of the same slope showing the rotation of

515 the block nearest the coast. Images kindly provided by Reginald Hermanns.

516

517 Deep seated gravitational slope deformation (DSGSD, also called "sagging" or

518 "sackung", Figure 8) are one of the adjustment processes which can be detected in 
519 paraglacial setting and can be categorized as mountain slope deformation of steep,

520 high mountain slopes, manifested by scarps and cracks, but lacking a defined rupture

521 surface and slow movement rates (Hungr et al., 2014). DSGSD are large mass

522 movements with long duration slow motion processes that can experience irregular

523 rates of activity characterized by periods of rapid reactivating (Pánek et al. 2013) which

524 often result in high volume and long-runout events (Hewitt et al., 2008; Hewitt, 525 2009a,b,c; Mege and Bourgeois, 2011; Pánek \& Klimeš, 2016; Pedrazzini et al., 2013).

526 The firsts observations of the geomorphic role and impact of DSGSD dates back to the

527 1940s, but recent developments in remote sensing, e.g. Insar have made it easier to 528 detect these slow movements which has led to increasing understanding and 529 recognition of DSGSD (e.g. Ambrosi and Crosta, 2006; Colesanti and Wasowski, 530 2006; Hilley et al., 2004; Saroli et al., 2005; Teshebaeva et al. 2019).

531 DSGSD have been observed in various rock types and are generally characterized 532 by discontinuous or poorly defined lateral boundaries (Ambrosi and Crosta, 2006; 533 Varnes et al., 1990). According to Agliardi et al. (2001) diagnostic features of DSGSD 534 ca include: "morpho-structures (doubled ridges, scarps, counterscarps, etc.) similar to 535 those observable, at a smaller scale, in cohesive soils landslides; size of the 536 phenomenon comparable to the slope; present day low rate of displacement $(\mathrm{mm} / \mathrm{y}$, in 537 alpine and prealpine areas); presence of minor landslides inside the deformed mass 538 and ancient collapses of the lower part of the slope".

539 DSGSD are not considered as imminent hazardous phenomena because of their 540 slow movement rate, but a part of the creeping mass can evolve into multiple 541 sequential failures or into fast large catastrophic slope failures such as rockslides and 542 rock avalanche (Agliardi et al. 2012). These large-scale events, even though they are 543 infrequent, can cause hazardous conditions e.g. on glaciers and surrounding areas 544 (e.g. Deline et al. 2015b; Dufresne et al. 2019; Hewitt et al. 2011), in fjord environments 
545 were rock-slope failures can generate tsunamis (Böhme et al. 2011; Kuhn et al. 2019)

546 and in valley systems were large rock-slope failures can dam rivers (Oppikofer et al.,

547 2020; Strom and Korup, 2006).

548 Many case studies of DSGSD have been described in various settings around the 549 world, but it is difficult to understand their controlling factors due to the variety of 550 geologic and environmental settings which they occur in (Agilardi et al. 2012). They 551 are widespread in orogenic mountain ranges (Ambrosi and Crosta, 2006; Agliardi et 552 al. 2009; 2012; Korup, 2006;), and have been described from the Central-Eastern Alps 553 (Forcella, 1984; Forcella and Orombelli, 1984; Zischinsky, 1966), Norway (Böhme et al. 2013; Oppikofer et al. 2017; Schleier et al. 2016), Spitsbergen (Figure 8) (Kuhn et 555 al. 2019; 2021), Iceland (Coquin et al. 2015; 2019) and other places.

Research challenges, on mass movements in Paraglacial environments and in some extend in Periglacial environments, have during the last decades focused more and more on the hidden hazard which DSGSD can cause to human habitation in these environments. Recent and future developments in remote sensing will without doubt deepen our understanding on the physical mechanisms and triggering factors for DSGSD. These developments will improve our monitoring and hazard analyses.

\section{Climate change and hazard of mass movements in cold and}

564 polar climates

565 According to the definition of (Varnes, 1984), landslide hazard is defined as the 566 probability that a landslide event of a certain magnitude occurs within a period of time 567 in a given area. Landslide risk - as any other risk - refers to the expected degree of 568 loss due to a landslide event, and it is the result of the product of the landslide hazard and the vulnerability, with the latter being the degree to which a community, a structure, 
570 a service or an area is likely to be damaged by a hazardous phenomenon (UNDHA,

571 1992). Mass movements can be extremely dangerous, as they are processes that can

572 severely threaten human life and affect infrastructures (Crozier and Glade, 2005;

573 Geertsema et al., 2009; Haque et al., 2016; Kjekstad and Highland, 2009; Petley,

574 2012). Slope failures can involve different types of materials and can have a great

575 diversity of velocities and fluid contents, making them hard to understand and produce

576 the appropriate countermeasures.

577 Even if high level of uncertainty of global-climate predictions and the lack of spatial

578 resolution of the available downscaled projections, there is a strong theoretical basis

579 for increased landslide activity as a result of climate change (Borgatti and Soldati,

580 2010; Crozier, 2010; Gariano and Guzzetti, 2016; Haque et al., 2019; Wood et al.,

581 2020). There are few studies (Coe, 2020; Coe et al., 2018; Schlögel et al., 2011;

582 UhImann et al., 2013) that systematically evaluate and compare the magnitude,

583 frequency, and extent of landslide events in glacial and periglacial environments on

584 the long term (Allen et al., 2011; Bessette-Kirton and Coe, 2020; Hock et al., 2019).

585 Cold environments are particularly sensitive to variations in atmospheric temperatures

586 (Clague et al., 2012b; Huggel et al., 2012) that lead to an enhanced reaction of slopes

587 to glacial retreat and permafrost degradation (e.g., Gruber et al., 2017; Gruber and

588 Haeberli, 2007; Harris et al., 2009; Hock et al., 2019; Kos et al., 2016; Patton et al.,

589 2019a; Schoeneich et al., 2011). As result of climate change, mass movements in

590 cryospheric regions can be triggered by warming periods, freeze-thaw, rapid

591 snowmelt, intense and/or prolonged precipitation (Huggel et al., 2012, 2010; Stoffel

592 and Huggel, 2012). From a hazard perspective, understanding how these factors will

593 impact failures' frequency and magnitude is becoming increasingly important.

594 In glacial environments, retreat and thinning of glacial ice reduces lateral support of 
596 debutressing steep valley walls (Lane et al., 2017), that are impacted by modifications

597 in the stress field and subject to mechanical and thermal alteration, and consequently 598 slope instabilities (Cody et al., 2020; Coquin et al., 2015; Evans and Clague, 1994; 599 Grämiger et al., 2017; McColl, 2012; McColl and Draebing, 2019; Mercier et al., 2017; 600 Wegmann et al., 1998). Failures linked to glacial retreat can range from small-scale 601 rock fall to catastrophic rock/debris avalanches. As glacial environments are highly 602 dynamic because of increasing atmospheric temperatures, the landslide hazard in 603 these regions is more difficult to assess because of the changing zones of instability 604 and initiation (e.g., Evans and Clague, 1988; Geertsema et al., 2006a,b; Kääb et al., 605 2005). The consequences of landslides in glacial environments can be more 606 unexpected and severe than the events themselves, generating hazardous consequences because of dam-creation (Fan et al., 2020; Oppikofer et al., 2020; 608 Strom and Korup, 2006), or tsunami if they reach the water (Dahl-Jensen et al., 2004; 609 Dai et al., 2020; Dufresne et al., 2018a). A better understanding of changes in slope 610 stability caused by the loss of glacier ice could improve the definition of landslide 611 hazard zones, aiding to protect areas and populations exposed to these hazards 612 (Haeberli et al., 2017b; Hock et al., 2019).

613 Climate change is causing permafrost degradation at high latitudes and in mountain 614 regions (e.g., Blunden and Arndt, 2020; Slater and Lawrence, 2013), and this is 615 confirmed by local monitoring permafrost studies in the European Alps, Alaska, 616 Canada, Siberia, Iceland, Greenland, northern Europe, the Tibetan Plateau, the Andes 617 and the Antarctic Peninsula (Christiansen et al., 2010; Czekirda et al., 2019; Gisnås et 618 al., 2017; Harris et al., 2009; Panda et al., 2014; Pastick et al., 2015; Romanovsky et 619 al., 2010; Westermann et al., 2017; Zou et al., 2017). Among the consequences of 620 permafrost degradation, the most hazardous are mass movements like rock falls, 621 debris flows, rock/debris avalanches (Darrow et al., 2017; Deline et al., 2015a; 
622 Huscroft et al., 2004; Patton et al., 2019a; Schoeneich et al., 2011). Mountains host $62312 \%$ of the global population (Schild, 2008), and about a quarter of the permafrost on

624 Earth is hosted in mountainous terrains (Gruber, 2012). Therefore, mass movements 625 in periglacial mountain environments pose at direct risk the local population and 626 infrastructure (e.g., Haeberli, 2013; Schoeneich et al., 2011), and can impact local 627 economies and tourism, communication and transport systems and power generation 628 industries (e.g., Arenson and Jakob, 2017; Duvillard et al., 2019; Mourey et al., 2019; 629 Pröbstl-Haider et al., 2016). The unpredictability of the extension and speed of 630 permafrost degradation makes the understanding of landslide processes in mountain 631 periglacial environments even more urgent, in order to predict and mitigate their 632 hazardous consequences.

633 Due to their magnitude and mobility, rock/ices avalanches are also particularly 634 hazardous in both glacial and periglacial environments (Davies and McSaveney, 2012; 635 Evans and Clague, 1988; Geertsema et al., 2006a, 2006b; Hungr and Evans, 2004). 636 Several examples with volumes ranging up to millions of cubic metres include the 637 rock/ice avalanche from Monte Rosa in the western Italia Alps in 2007 (Fischer et al., 638 2011), the rock/ice avalanches at Mount Munday in 1997 and at Kendall Glacier in 6391999 in British Columbia (Delaney and Evans, 2014; Geertsema et al., 2006a), the 6402005 Mt. Steller rock/ice avalanche in Alaska (Huggel et al., 2008), the 2002 rock/ice 641 avalanche at Kolka/Karmadon, Russian Caucasus, with the latter one causing the 642 death of 140 people (Evans et al., 2009c; Haeberli et al., 2004; Huggel et al., 2005). 643 Hazard related to mass movements in both glacial and periglacial environments 644 include also catastrophic phenomena such as glacial lake outburst floods (GLOFs). 645 GLOFs are floods that originate from lakes formed behind a landslide dam (Fan et al., 646 2020; Oppikofer et al., 2020; Strom and Korup, 2006) or dammed by a frontal moraine 647 or glacial ice (Carey et al., 2012; Clague and Evans, 2000; Cook et al., 2016; Haeberli 
648 et al., 2016; Harrison et al., 2018; Hubbard et al., 2005; Richardson and Reynolds, 649 2000; Veh et al., 2019; Westoby et al., 2014). The lakes can drain catastrophically for 650 several reasons, including mass movements into the lake (Figure 9) (Costa and 651 Schuster, 1988; Korup and Tweed, 2007). Their influence on settlements and infra652 structure can be devastating (e.g. Kjartansson 1967; Dahl-Jensen et al., 2004; Stoffel 653 \& Huggel, 2012; Dai et al., 2020; Deline et al., 2015b; Dufresne et al., 2018a, b). In 654 regions like the Himalaya, GLOFs have been recognised as the dominant long-term 655 drivers of fluvial erosion and valley evolution (Cook et al., 2018). They are extremely 656 destructive due to their magnitude and unpredictability (Khanal et al., 2015; Mool et 657 al., 2011; Schwanghart et al., 2016; Shrestha et al., 2010). GLOFs' frequency and 658 magnitude are thought to be increasing in response to climate change (Bajracharya 659 and Mool, 2009; Bolch et al., 2011; Dussaillant et al., 2010; Harrison et al., 2018; Lutz 660 et al., 2016). This is due to the fact that outlet glaciers have thinned and retreated from 661 their basins, resulting often in unstable slopes combined with accelerated formation 662 and rapid growth of proglacial lakes (e.g. Guðmundsson et al. 2019; IPCC, 2012). 


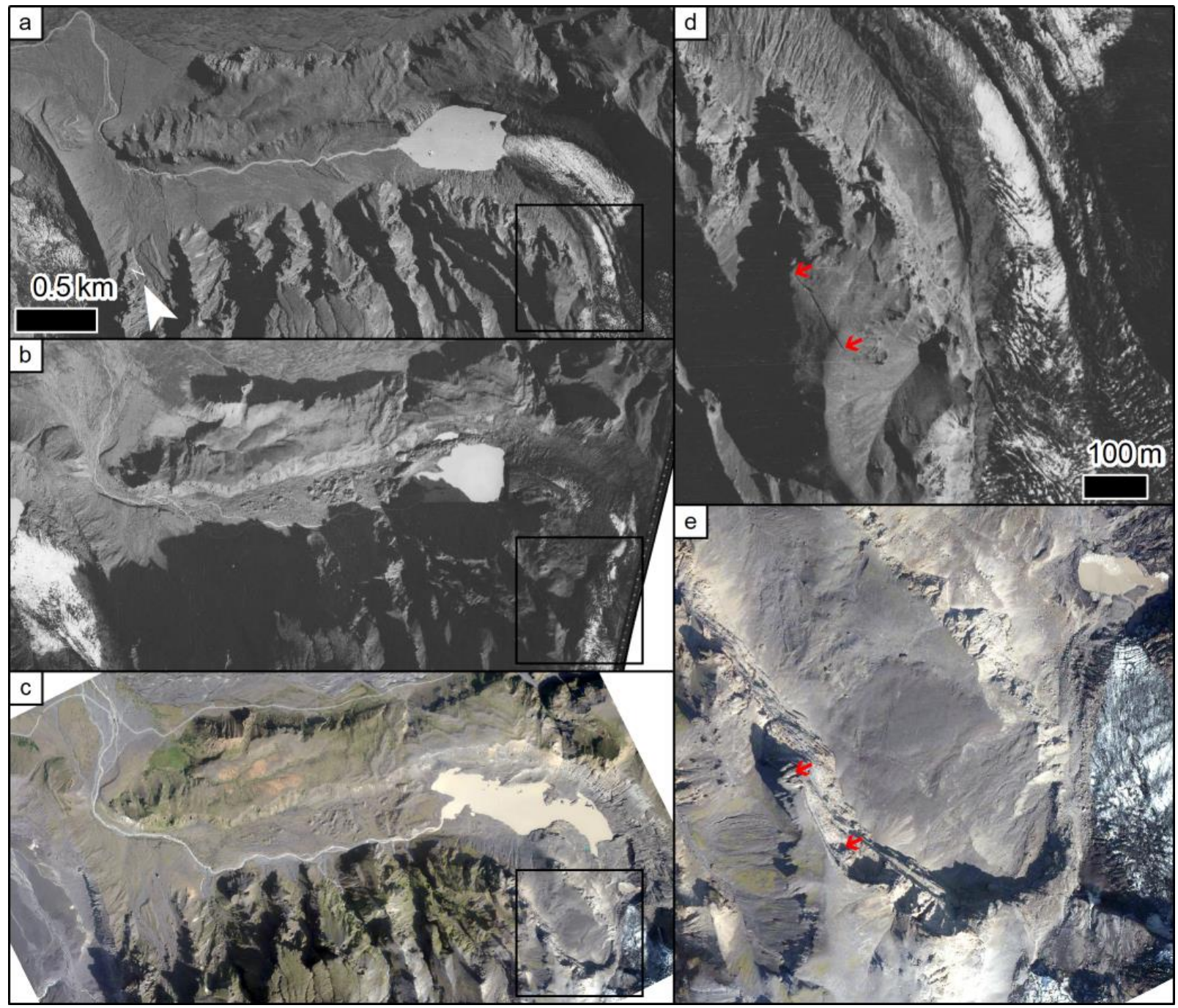

Figure 9. The Steinsholtsjökull rockslide and the GLOF in the Steinsholtsdalur valley

666 in 1967. The extent of panels $d$ and e are shown as black boxes on panels a-c. (a)

667 Aerial photograph taken in August 1960 (b) Aerial photograph taken in September

668 1967, eight months after the rock slide. (c) Modern image showing clearly that the

669 headwall of the slide was about $900 \mathrm{~m}$ long. (d) Detailed view showing a $100 \mathrm{~m}$ long

670 fracture in the Innstihaus above the Steinsholtsjökull outlet glacier. (e) Same view as

671 in panel $d$, but using the modern image shown in panel $c$ to illustrate the amount of

672 material mobilised. Aerial images are from the National Land Survey of Iceland.

673

674 Landslides and mass movements such as active-layer-detachment slides and thaw

675 slumps in degrading-permafrost terrains can impact on the environments in which they 
676 occur. The physical and ecological structure of hillslopes and fluvial networks can be

677 affected by an increased sediment, nutrients, and soil displacement of mass

678 movements (Abbott and Jones, 2015b; Bowden et al., 2008; Gooseff et al., 2009;

679 Osterkamp et al., 2009; Turetsky et al., 2019; Zongxing et al., 2016). These

680 phenomena can generate disturbance to terrestrial and aquatic ecosystems (Bowden

681 et al., 2008; Callaghan et al., 2011; Cannone et al., 2010; Osterkamp et al., 2009;

682 Racine et al., 2004). An increase in mass movements occurrence in cold and polar

683 terrains due to permafrost thaw because of the warming climate may also accelerate

684 the release to the atmosphere of Pleistocene sequestered carbon (Belshe et al., 2013;

685 Grosse et al., 2011; Masyagina et al., 2019; Pautler et al., 2010; Schuur et al., 2009,

686 2008; Tarnocai et al., 2009). Thaw-slumps and active-layer-detachment-slides activity

687 in the Arctic has enhanced in the last decades (Jorgenson and Osterkamp, 2005; Luo

688 et al., 2019), generating alterations in the water quality of nearby lakes and streams

689 (Kokelj et al., 2013; Lafrenière and Lamoureux, 2019; Segal et al., 2016), vegetation

690 and soils (Khomutov and Leibman, 2014; Lantuit et al., 2012), and trace gases (Abbott 691 and Jones, 2015).

692

693 6. Conclusions

694 In this chapter, we emphasized the major types of rapid mass movements that 695 reflect the most characteristic expression of rapid down-slope sediment transport in 696 cold and polar environments under glacial, periglacial and paraglacial conditions.

697 Many of these rapid mass wasting processes are not exclusive to the glacial, 698 periglacial and paraglacial domains, but we highlighted that permafrost and ice are the 699 critical agent in their development. We focussed on the specific attributes that 700 distinguish these mass movements from ones in other environments and the 


\section{References}

Abbott, B.W., Jones, J.B., 2015. Permafrost collapse alters soil carbon stocks, respiration, $\mathrm{CH}_{4}$, and $\mathrm{N}_{2} \mathrm{O}$ in upland tundra. Glob. Chang. Biol. 21, 4570-4587.

Abbott, B.W., Jones, J.B., Godsey, S.E., Larouche, J.R., Bowden, W.B., 2015. Patterns and persistence of hydrologic carbon and nutrient export from collapsing upland permafrost. Biogeosciences Discuss. 12.

Agliardi, F., Crosta, G. and Zanchi, A. (2001). Structural constraints on deep-seated slope deformation kinematics. Engineering Geology, 59, 83-102.

Agliardi, F., Crosta, G. B., Zanchi, A. and Ravazzi, C. (2009). Onset and timing of deep-seated gravitational slope deformations in the eastern Alps, Italy. Geomorphology, 103, 113-129.

Agliardi, F., Crosta, G.B. and Frattini, P. 2012. Slow rock slope deformations. In: Clague, J.J \& Stead, D.(eds). Landslides Types, Mechanisms and Modeling, 207-221. Cambridge University Press.

Alexeev, V.A., Jackson, C.H., 2013. Polar amplification: is atmospheric heat transport important? Clim. Dyn. 41, 533-547.

Allen, S., Huggel, C., 2013. Extremely warm temperatures as a potential cause of recent high mountain rockfall. Glob. Planet. Change 107, 59-69.

Allen, S.K., Cox, S.C., Owens, I.F., 2011. Rock avalanches and other landslides in the central Southern Alps of New Zealand: A regional study considering possible climate change impacts. Landslides 8, 33-48. https://doi.org/10.1007/s10346-010-0222-z

Ambrosi, C. and Crosta, G. B. (2006). Large sackung along major tectonic features in the central Italian Alps. Engineering Geology, 83, 183-200.

Andersson, J.G., 1906. Solifluction, a Component of Subaërial Denudation. J. Geol. 14, 91-112.

André, M.-F., 1990. Frequency of debris flows and slush avalanches in Spitsbergen: a tentative evaluation from lichenometry. Pol. Polar Res. 11, 345-363.

Arenson, L.U., Jakob, M., 2017. Permafrost-related geohazards and infrastructure construction in mountainous environments, in: Oxford Research Encyclopedia of Natural Hazard Science.

Ashastina, K., Schirrmeister, L., Fuchs, M., Kienast, F., 2017. Palaeoclimate characteristics in interior Siberia of MIS 6-2: First insights from the Batagay permafrost mega-thaw slump in the Yana Highlands. Clim. Past 13, 795-818. https://doi.org/10.5194/cp-13-795-2017

Bajracharya, S.R., Mool, P., 2009. Glaciers, glacial lakes and glacial lake outburst floods in the Mount Everest region, Nepal. Ann. Glaciol. 50, 81-86.

Ballantyne, C.K., 2002. Paraglacial geomorphology. Quat. Sci. Rev. 21, 1935-2017.

Ballantyne, C.K., Harris, C., 1994. The Periglaciation of Great Britain. Cambridge University Press, Cambridge.

Balser, A.W., Gooseff, M.N., Jones, J.B., Bowden, W.B., 2009. Thermokarst distribution and relationships to landscape characteristics in the Feniak Lake region, Noatak National Preserve, Alaska.

Bartelt, P., Glover, J., Feistl, T., Bühler, Y., Buser, O., 2012. Formation of levees and en-echelon shear planes during snow avalanche run-out. J. Glaciol. 58, 980-992. https://doi.org/10.3189/2012JoG11J011

Beamish, A., Neil, A., Wagner, I., Scott, N.A., 2014. Short-term impacts of active layer detachments on carbon exchange in a High Arctic ecosystem, Cape Bounty, Nunavut, Canada. Polar Biol. 37, 1459-1468.

Behnia, P., \& Blais-Stevens, A. (2018). Landslide susceptibility modelling using the quantitative random 
forest method along the northern portion of the Yukon Alaska Highway Corridor, Canada. Natural hazards, 90(3), 1407-1426.

Belshe, E.F., Schuur, E.A.G., Bolker, B.M., 2013. Tundra ecosystems observed to be CO2 sources due to differential amplification of the carbon cycle. Ecol. Lett. 16, 1307-1315.

Bessette-Kirton, E.K., Coe, J.A., 2020. A 36-year record of rock avalanches in the Saint Elias Mountains of Alaska, with implications for future hazards. Front. Earth Sci. 8, 293.

Biskaborn, B.K., Smith, S.L., Noetzli, J., Matthes, H., Vieira, G., Streletskiy, D.A., Schoeneich, P., Romanovsky, V.E., Lewkowicz, A.G., Abramov, A., Allard, M., Boike, J., Cable, W.L., Christiansen, H.H., Delaloye, R., Diekmann, B., Drozdov, D., Etzelmüller, B., Grosse, G., Guglielmin, M., Ingeman-Nielsen, T., Isaksen, K., Ishikawa, M., Johansson, M., Johannsson, H., Joo, A., Kaverin, D., Kholodov, A., Konstantinov, P., Kröger, T., Lambiel, C., Lanckman, J.P., Luo, D., Malkova, G., Meiklejohn, I., Moskalenko, N., Oliva, M., Phillips, M., Ramos, M., Sannel, A.B.K., Sergeev, D., Seybold, C., Skryabin, P., Vasiliev, A., Wu, Q., Yoshikawa, K., Zheleznyak, M., Lantuit, H., 2019. Permafrost is warming at a global scale. Nat. Commun. 10, 1-11. https://doi.org/10.1038/s41467018-08240-4

Black, R.F., 1954. Permafrost: a review. Geol. Soc. Am. Bull. 65, 839-856.

Blais-Stevens, A., Geertsema, M., Schwab, J.W., Van Asch, T.W.J., 2015. Complex Landslide Triggered in an Eocene Volcanic-Volcaniclastic Succession along Sutherland River, British Columbia, Canada. Environ. Eng. Geosci. 21, 35-45. https://doi.org/10.2113/gseegeosci.21.1.35

Blikra, L.H., Longva, O., Braathen, A., Anda, E., Dehls, J.F., Stalsberg, K., 2006. Rock slope failures in Norwegian fjord areas: examples, spatial distribution and temporal pattern, in: Landslides from Massive Rock Slope Failure. Springer, pp. 475-496.

Blunden, J., Arndt, D.S., 2020. State of the Climate in 2019. Bull. Am. Meteorol. Soc. 101, S1-S429.

Bockheim, J., Vieira, G., Ramos, M., López-Martínez, J., Serrano, E., Guglielmin, M., Wilhelm, K., Nieuwendam, A., 2013. Climate warming and permafrost dynamics in the Antarctic Peninsula region. Glob. Planet. Change 100, 215-223.

Böhme, M., Hermanns, R. L., Oppikofer, T., Fischer, L., Bunkholt, H. S., Eiken, T., Pedrazzini, A., Derron, M.-H., Jaboyedoff, M., and Blikra, L. H., 2013, Analyzing complex rock slope deformation at Stampa, western Norway, by integrating geomorphology, kinematics and numerical modeling: Engineering Geology, v. 154, p. 116-130.

Bolch, T., Pieczonka, T., Benn, D.I., 2011. Multi-decadal mass loss of glaciers in the Everest area (Nepal Himalaya) derived from stereo imagery. Cryosph. 5, 349-358.

Borgatti, L., Soldati, M., 2010. Landslides and climatic change. Geomorphol. hazards disaster Prev. 8795.

Bowden, W.B., Gooseff, M.N., Balser, A., Green, A., Peterson, B.J., Bradford, J., 2008. Sediment and nutrient delivery from thermokarst features in the foothills of the North Slope, Alaska: Potential impacts on headwater stream ecosystems. J. Geophys. Res. Biogeosciences 113.

Burki, V., Larsen, E., Fredin, O., Nesje, A., 2009. Glacial remobilization cycles as revealed by lateral moraine sediment, Bødalsbreen glacier foreland, western Norway. The Holocene 19, 415-426. https://doi.org/10.1177/0959683608101391

Burn, C.R., Friele, P.A., 1989. Geomorphology, vegetation succession, soil characteristics and permafrost in retrogressive thaw slumps near Mayo, Yukon Territory. Arctic 31-40.

Callaghan, T. V, Tweedie, C.E., Åkerman, J., Andrews, C., Bergstedt, J., Butler, M.G., Christensen, T.R., Cooley, D., Dahlberg, U., Danby, R.K., 2011. Multi-decadal changes in tundra environments and ecosystems: synthesis of the International Polar Year-Back to the Future Project (IPY-BTF). Ambio 40, 705.

Cannone, N., Ellis Evans, J.C., Strachan, R., Guglielmin, M., 2006. Interactions between climate, vegetation and the active layer in soils at two Maritime Antarctic sites. Antarct. Sci. 18, 323.

Cannone, N., Lewkowicz, A.G., Guglielmin, M., 2010. Vegetation colonization of permafrost-related landslides, Ellesmere Island, Canadian High Arctic. J. Geophys. Res. Biogeosciences 115.

Carey, M., Huggel, C., Bury, J., Portocarrero, C., Haeberli, W., 2012. An integrated socio-environmental framework for glacier hazard management and climate change adaptation: lessons from Lake 513, Cordillera Blanca, Peru. Clim. Change 112, 733-767.

Church, M. \& Ryder, J.M. 1972. Paraglacial Sedimentation: A Consideration of Fluvial Processes Conditioned by Glaciation. Geological Society of America Bulletin, v. 83, p. 3059-3072, DOI:10.1130/0016-7606(1972)83[3059:PSACOF]2.0.CO;2

Chinn, T.J. \& McSaveney, M.J. 1992: The Mount Cook rock avalanche of 14 December 1991. Institute of Geological and Nuclear Sciences Ltd., New Zealand.

Christiansen, H.H., Etzelmüller, B., Isaksen, K., Juliussen, H., Farbrot, H., Humlum, O., Johansson, M., Ingeman-Nielsen, T., Kristensen, L., Hjort, J., 2010. The thermal state of permafrost in the nordic area during the international polar year 2007-2009. Permafr. Periglac. Process. 21, 156-181. 
Clague, J.J., Evans, S.G., 2000. A review of catastrophic drainage of moraine-dammed lakes in British Columbia. Quat. Sci. Rev. 19, 1763-1783.

Clague, J.J., Huggel, C., Korup, O., Mcguire, B., 2012a. Climate Change and Hazardous Processes in High Mountains. Rev. la Asoc. Geológica Argentina 69, 328-338. https://doi.org/10.5167/uzh77920

Clague, J.J., Huggel, C., Korup, O., McGuire, B., 2012b. Climate change and hazardous processes in high mountains. Rev. la Asoc. Geol. Argentina 69, 328-338. https://doi.org/10.5167/uzh-77920

Cody, E., Anderson, B.M., McColl, S.T., Fuller, I.C., Purdie, H.L., 2020. Paraglacial adjustment of sediment slopes during and immediately after glacial debuttressing. Geomorphology 371, 107411.

Coe, J.A., 2020. Bellwether sites for evaluating changes in landslide frequency and magnitude in cryospheric mountainous terrain: a call for systematic, long-term observations to decipher the impact of climate change. Landslides 1-19.

Coe, J.A., Bessette-Kirton, E.K., Geertsema, M., 2018. Increasing rock-avalanche size and mobility in Glacier Bay National Park and Preserve, Alaska detected from 1984 to 2016 Landsat imagery. Landslides 15, 393-407.

Colesanti, C. and Wasowski, J., 2006. Investigating landslides with spaceborne Synthetic Aperture Radar (SAR) interferometry. Engineering Geology 88(3-4): 173-199. https://doi.org/10.1016/j.enggeo.2006.09.013.

Cook, K.L., Andermann, C., Gimbert, F., Adhikari, B.R., Hovius, N., 2018. Glacial lake outburst floods as drivers of fluvial erosion in the Himalaya. Science (80-. ). 362, 53-57.

Cook, S.J., Kougkoulos, I., Edwards, L.A., Dortch, J., Hoffmann, D., 2016. Glacier change and glacial lake outburst flood risk in the Bolivian Andes. Cryosph. 10, 2399-2413.

Cook, S.J., Porter, P.R., Bendall, C.A., 2013. Geomorphological consequences of a glacier advance across a paraglacial rock avalanche deposit. Geomorphology 189, 109-120. https://doi.org/10.1016/j.geomorph.2013.01.022

Coquin, J., Mercier, D., Bourgeois, O., Cossart, E., Decaulne, A., 2015. Gravitational spreading of mountain ridges coeval with Late Weichselian deglaciation: Impact on glacial landscapes in Tröllaskagi, northern Iceland. Quat. Sci. Rev. 107, 197-213. https://doi.org/10.1016/j.quascirev.2014.10.023

Coquin, J., Mercier, D., Bourgeois, O. and Decaulne, A., 2019. A paraglacial rock-slope failure origin for cirques: a case study from Northern lceland. Géomorphologie: relief, processus, environnement. Vol. 25 -No2. P. 117-136. https://doi.org/10.4000/geomorphologie.13057

Cossart, E., Mercier, D., Decaulne, A., Feuillet, T., Jónsson, H.P., Sæmundsson, T., 2014. Impacts of post-glacial rebound on landslide spatial distribution at a regional scale in northern Iceland (Skagafjörur). Earth Surf. Process. Landforms 39, 336-350. https://doi.org/10.1002/esp.3450

Costa, J.E., 1984. Physical geomorphology of debris flows. Dev. Appl. Geomorphol. https://doi.org/10.1007/978-3-642-69759-3_9

Costa, J.E., Schuster, R.L., 1988. The formation and failure of natural dams. Geol. Soc. Am. Bull. 100, 1054-1068.

Couture, R., Riopel, S., 2008. Regional landslide susceptibility mapping and inventorying in the Mackenzie Valley, Northwest Territories, in: Proceedings of the 4th Canadian Conference on Geohazards: From Causes to Management, Presse de l'Université Laval, Québec. pp. 375-382.

Crandell, D.R. \& Fahnestock, R.F. 1965: Rockfalls and avalanches from Little Tahoma Peak on Mount Rainier, Washington. Geological Survey Bulletin 1221A. 30 pp.

Crosta, G. B., Chen, H., \& Lee, C. F. (2004). Replay of the 1987 Val Pola landslide, Italian alps. Geomorphology, 60(1-2), 127-146.

Crozier, M. 1989 Landslides: Causes, Consequences And Environment, Helm, London, p. 252, https://doi.org/10.1111/j.1745-7939.1989.tb01143.x.

Crozier, M., 2002. Landslides, in: Applied Geography. Routledge, pp. 111-122.

Crozier, M.J., 2010. Deciphering the effect of climate change on landslide activity: A review. Geomorphology 124, 260-267. https://doi.org/10.1016/j.geomorph.2010.04.009

Crozier, M.J., Glade, T., 2005. Landslide hazard and risk: issues, concepts and approach. Landslide hazard risk 1-40.

Cruden, D.M., Varnes, D..., 1996. Landslide types and processes, in: Transportation research board, U.N.R.C. (Ed.), Landslides Investigation and Mitigation. Washington, DC, pp. 36-75.

Czekirda, J., Westermann, S., Etzelmüller, B., Jóhannesson, T., 2019. Transient modelling of permafrost distribution in Iceland. Front. Earth Sci. 7, 1-23. https://doi.org/10.3389/feart.2019.00130

D'Agata, C., Zanutta, A., 2007. Reconstruction of the recent changes of a debris-covered glacier (Brenva Glacier, Mont Blanc Massif, Italy) using indirect sources: Methods, results and validation. Glob. Planet. Change 56, 57-68. https://doi.org/10.1016/j.gloplacha.2006.07.021 
Dahl-Jensen, T., Larsen, L.M., Pedersen, S.A.S., Pedersen, J., Jepsen, H.F., Pedersen, G.K., Nielsen, T., Pedersen, A.K., Von Platen-Hallermund, F., Weng, W., 2004. Landslide and tsunami 21 November 2000 in Paatuut, West Greenland. Nat. Hazards 31, 277-287. https://doi.org/10.1023/B:NHAZ.0000020264.70048.95

Dai, C., Higman, B., Lynett, P.J., Jacquemart, M., Howat, I.M., Liljedahl, A.K., Dufresne, A., Freymueller, J.T., Geertsema, M., Ward Jones, M., 2020. Detection and assessment of a large and potentiallytsunamigenic periglacial landslide in Barry Arm, Alaska. Geophys. Res. Lett. e2020GL089800.

Darrow, M.M., Daanen, R.P., Gong, W., 2017. Predicting movement using internal deformation dynamics of a landslide in permafrost. Cold Reg. Sci. Technol. 143, 93-104.

Davies, M.C., Hamza, O., Harris, C., 2001. The effect of rise in mean annual temperature on the stability of rock slopes containing ice-filled discontinuities. Permafr. Periglac. Process. 12, 137-144. https://doi.org/10.1002/ppp

Davies, T.R.H., McSaveney, M.J., 2012. Mobility of long-runout rock avalanches, in: Landslides: Types, Mechanisms and Modeling. Cambridge University Press, pp. 50-58.

Decaulne, A., Saemundsson, P., 2006a. Meteorological conditions during slush-flow release and their geomorphological impact in northwestern Iceland: A case study from the Bildudalur valley. Geogr Ann Ser -Phys Geogr 88A, 187-197.

Decaulne, A., Saemundsson, T., 2006b. Geomorphic evidence for present-day snow-avalanche and debris-flow impact in the Icelandic Westfjords. Geomorphology 80, 80-93. https://doi.org/10.1016/j.geomorph.2005.09.007

Decaulne, A., Sæmundsson, P., 2010. Distribution and frequency of snow-avalanche debris transfer in the distal part of colluvial cones in central north iceland. Geogr. Ann. Ser. Phys. Geogr. 92, 177187. https://doi.org/10.1111/j.1468-0459.2010.00388.x

Delaney, K.B., Evans, S.G., 2014. The 1997 Mount Munday landslide (British Columbia) and the behaviour of rock avalanches on glacier surfaces. Landslides 11, 1019-1036.

Deline, P., 2009. Interactions between rock avalanches and glaciers in the Mont Blanc massif during the late Holocene. Quat. Sci. Rev. 28, 1070-1083.

Deline, P., Gruber, S., Delaloye, R., Fischer, L., Geertsema, M., Giardino, M., Hasler, A., Kirkbride, M., Krautblatter, M., Magnin, F., 2015a. Ice loss and slope stability in high-mountain regions, in: Snow and Ice-Related Hazards, Risks and Disasters. Elsevier, pp. 521-561.

Deline, P., Hewitt, K., Reznichenko, N. \& Shugar, D. 2015b: Rock avalanches onto Glaciers. In: Hazards and Disaster Series. Landslide Hazards, Risk and Disasters. Tim Davies (ed), 263-320.

Dobinski, W., 2011. Permafrost. Earth-Science Rev. 108, 158-169.

Draebing, D., 2020. Identification of rock and fracture kinematics in high Alpine rockwalls under the influence of altitude. Earth Surf. Dyn. Discuss. 1-31.

Draebing, D., Krautblatter, M., 2019. The efficacy of frost weathering processes in alpine rockwalls. Geophys. Res. Lett. 46, 6516-6524.

Draebing, D., Krautblatter, M., Hoffmann, T., 2017. Thermo-cryogenic controls of fracture kinematics in permafrost rockwalls. Geophys. Res. Lett. 44, 3535-3544.

Dramis, F., Govi, M., Guglielmin, M., Mortara, G., 1995. Mountain permafrost and slope instability in the Italian Alps: the Val Pola landslide. Permafr. Periglac. Process. 6, 73-81.

Dramis, F., Sorriso-Valvo, M., 1995. Deep-seated gravitational slope deformations, related landslides and tectonics. Int. J. Rock Mech. Min. Sci. Geomech. 5, 203A.

Dufresne, A., Davies, T.R., 2009. Longitudinal ridges in mass movement deposits. Geomorphology 105 , 171-181. https://doi.org/10.1016/j.geomorph.2008.09.009

Dufresne, A., Geertsema, M., Shugar, D.H., Koppes, M., Higman, B., Haeussler, P.J., Stark, C., Venditti, J.G., Bonno, D., Larsen, C., Gulick, S.P.S., McCall, N., Walton, M., Loso, M.G., Willis, M.J., 2018 a. Sedimentology and geomorphology of a large tsunamigenic landslide, Taan Fiord, Alaska. Sediment. Geol. 364, 302-318. https://doi.org/10.1016/j.sedgeo.2017.10.004

Dufresne, A., Ostermann, M., and Preusser, F. 2018b: River-damming, late-Quaternary rockslides in the Ötz Valley region (Tyrol, Austria). Geomorphology, 310,153-167, 2018.

Dufresne, A., Wolken, G.J., Hibert, C., Bessette-Kirton, E.K., Coe, J.A., Geertsema, M., Ekström, G., 2019. The 2016 Lamplugh rock avalanche, Alaska: deposit structures and emplacement dynamics. Landslides 16, 2301-2319. https://doi.org/10.1007/s10346-019-01225-4

Dunning, S.A., Rosser, N.J., McColl, S.T., Reznichenko, N.V., 2015. Rapid sequestration of rock avalanche deposits within glaciers. Nat. Commun. 6, 7964.

Dussaillant, A., Benito, G., Buytaert, W., Carling, P., Meier, C., Espinoza, F., 2010. Repeated glaciallake outburst floods in Patagonia: an increasing hazard? Nat. hazards 54, 469-481.

Duvillard, P.-A., Ravanel, L., Marcer, M., Schoeneich, P., 2019. Recent evolution of damage to infrastructure on permafrost in the French Alps. Reg. Environ. Chang. 19, 1281-1293.

Eckerstorfer, M., Christiansen, H.H., 2012. Meteorology, Topography and Snowpack Conditions 
causing Two Extreme Mid-Winter Slush and Wet Slab Avalanche Periods in High Arctic Maritime Svalbard: Two Mid-winter Slush and Wet Slab Avalanche Periods in Svalbard. Permafr. Periglac. Process. 23, 15-25. https://doi.org/10.1002/ppp.734

Ekstrom, G., Stark, C.P., 2013. Simple Scaling of Catastrophic Landslide Dynamics. Science 339, 14161419. https://doi.org/10.1126/science.1232887

Elder, K., Kattelmann, R., 1993. A low-angle slushflow in the Kirgiz Range, Kirgizstan. Permafr. Periglac. Process. 4, 301-310. https://doi.org/10.1002/ppp.3430040403

Evans, S.G., Clague, J.J., 1994. Recent climatic change and catastrophic geomorphic processes in mountain environments, in: Geomorphology and Natural Hazards. Elsevier, pp. 107-128.

Evans, S.G., Clague, J.J., 1988. Catastrophic rock avalanches in glacial environments, in: Bonnard, C. (Ed.), Landslides - Proceedings of the Fifth International Symposium on Landslides, Lausanne, Switzerland. Lausanne, Switzerland, pp. 1153-1158.

Evans, S.G., Bishop, N.F., Fidel Smoll, L., Valderrama Murillo, P., Delaney, K.B., Oliver-Smith, A., 2009a. A re-examination of the mechanism and human impact of catastrophic mass flows originating on Nevado Huascarán, Cordillera Blanca, Peru in 1962 and 1970. Eng. Geol. 108, 96118. https://doi.org/10.1016/j.enggeo.2009.06.020

Evans, S.G., Tutubalina, O.V., Drobyshev, V.N., Chernomorets, S.S., McDougall, S., Petrakov, D.A., Hungr, O., 2009b. Catastrophic detachment and high-velocity long-runout flow of Kolka Glacier, Caucasus Mountains, Russia in 2002. Geomorphology 105, 314-321. https://doi.org/10.1016/j.geomorph.2008.10.008

Evans, S.G., Tutubalina, O. V, Drobyshev, V.N., Chernomorets, S.S., McDougall, S., Petrakov, D.A., Hungr, O., 2009c. Catastrophic detachment and high-velocity long-runout flow of Kolka Glacier, Caucasus Mountains, Russia in 2002. Geomorphology 105, 314-321.

Falaschi, D., Kääb, A., Paul, F., Tadono, T., Rivera, J.A., Lenzano, L.E., 2019. Brief communication: Collapse of $4 \mathrm{Mm \& lt}$;sup\&gt;3\&lt;/sup\&gt; of ice from a cirque glacier in the Central Andes of Argentina. The Cryosphere 13, 997-1004. https://doi.org/10.5194/tc-13-997-2019

Fan, X., Dufresne, A., Subramanian, S.S., Strom, A., Hermanns, R., Stefanelli, C.T., Hewitt, K., Yunus, A.P., Dunning, S., Capra, L., 2020. The formation and impact of landslide dams-State of the art. Earth-Science Rev. 203, 103116.

Fischer, L., Huggel, C., Kääb, A., \& Haeberli, W. (2013). Slope failures and erosion rates on a glacierized high-mountain face under climatic changes. Earth surface processes and landforms, 38(8), 836-846.

Fischer, L., Eisenbeiss, H., Kääb, A., Huggel, C., Haeberli, W., 2011. Monitoring topographic changes in a periglacial high-mountain face using high-resolution DTMs, Monte Rosa East Face, Italian Alps. Permafr. Periglac. Process. 22, 140-152. https://doi.org/10.1002/ppp.717

Fischer, L., Huggel, C., 2008. Methodical design for stability assessments of permafrost-affected highmountain rock walls.

Fischer, L., Kääb, A., Huggel, C., Noetzli, J., 2006. Geology, glacier retreat and permafrost degradation as controlling factors of slope instabilities in a high-mountain rock wall: the Monte Rosa east face. Nat. Hazards Earth Syst. Sci. 6, 761-772. https://doi.org/10.5194/nhess-6-761-2006

Forcella, F., 1984. The Sackung between Mount Padrio and Mount Varadega, Central Alps, Italy: a

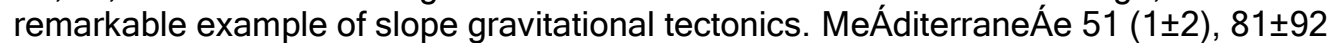

Forcella, F., Orombelli, G., 1984. Holocene slope deformations in Valfurva, Central Alps, Italy. Geogr.

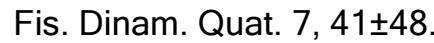

Frauenfelder, R., Isaksen, K., Lato, M.J., Noetzli, J., 2018. Ground thermal and geomechanical conditions in a permafrost-affected high-latitude rock avalanche site (Polvartinden, northern Norway). Cryosph. 12, 1531-1550.

French, H.M., 2007. The periglacial environment, Third Edit. ed, The Periglacial Environment. https://doi.org/10.1016/0031-0182(71)90005-8

Frost, G. V, Epstein, H.E., Walker, D.A., Matyshak, G., Ermokhina, K., 2018. Seasonal and long-term changes to active-layer temperatures after tall shrubland expansion and succession in Arctic tundra. Ecosystems 21, 507-520.

Gariano, S.L., Guzzetti, F., 2016. Landslides in a changing climate. Earth-Science Rev. 162, $227-252$. https://doi.org/10.1016/j.earscirev.2016.08.011

Geertsema, M., Clague, J.J., Schwab, J.W., Evans, S.G., 2006a. An overview of recent large catastrophic landslides in northern British Columbia, Canada. Eng. Geol. 83, 120-143.

Geertsema, M., Hungr, O., Schwab, J.W., Evans, S.G., 2006b. A large rockslide - Debris avalanche in cohesive soil at Pink Mountain, northeastern British Columbia, Canada. Eng. Geol. 83, 64-75. https://doi.org/10.1016/j.enggeo.2005.06.025

Geertsema, M., Highland, L., Vaugeouis, L., 2009. Environmental impact of landslides, in: LandslidesDisaster Risk Reduction. Springer, pp. 589-607. 

2018. Mechanisms leading to the 2016 giant twin glacier collapses, Aru Range, Tibet. The Cryosphere 12, 2883-2900. https://doi.org/10.5194/tc-12-2883-2018

Gisnås, K., Etzelmüller, B., Lussana, C., Hjort, J., Sannel, A.B.K., Isaksen, K., Westermann, S., Kuhry P., Christiansen, H.H., Frampton, A., 2017. Permafrost map for Norway, Sweden and Finland. Permafr. Periglac. Process. 28, 359-378.

Gooseff, M.N., Balser, A., Bowden, W.B., Jones, J.B., 2009. Effects of hillslope thermokarst in northern Alaska. Eos, Trans. Am. Geophys. Union 90, 29-30.

Grämiger, L.M., Moore, J.R., Gischig, V.S., Ivy-Ochs, S., Loew, S., 2017. Beyond debuttressing: Mechanics of paraglacial rock slope damage during repeat glacial cycles. J. Geophys. Res. Earth Surf. 122, 1004-1036.

Grosse, G., Romanovsky, V., Jorgenson, T., Anthony, K.W., Brown, J., Overduin, P.P., 2011. Vulnerability and Feedbacks of Permafrost to Climate Change. Eos, Trans. Am. Geophys. Union 92, 73-74. https://doi.org/10.1029/2011E0090001

Gruber, S., 2012. Derivation and analysis of a high-resolution estimate of global permafrost zonation Cryosph. 6, 221-233.

Gruber, S., Fleiner, R., Guegan, E., Panday, P., Schmid, M.-O., Stumm, D., Wester, P., Zhang, Y., Zhao, L., 2017. Inferring permafrost and permafrost thaw in the mountains of the Hindu Kush Himalaya region.

Gruber, S., Haeberli, W., 2007. Permafrost in steep bedrock slopes and its temperatures-related destabilization following climate change. J. Geophys. Res. Earth Surf. 112, 1-10. https://doi.org/10.1029/2006JF000547

Gude, M., Scherer, D., 1995. Snowmelt and slush torrents - preliminary report from a field campaign in Karkevagge, Swedish Lappland. Geogr. Ann. Ser. A 77 A, 199-206.

Guðmundsson, S., Björnsson, H., Pálsson, F., Magnússon, E., Sæmundsson, P. \& Jóhannesson, T. 2019: Terminus lagoons on the south side of Vatnajökull ice cap, SE-Iceland. Jökull, 69. 1-34.

Guglielmin, M., 2012. Advances in permafrost and periglacial research in Antarctica: a review. Geomorphology 155, 1-6.

Haeberli, W., 2013. Mountain permafrost - research frontiers and a special long-term challenge. Cold Reg. Sci. Technol. 96, 71-76. https://doi.org/10.1016/j.coldregions.2013.02.004

Haeberli, W., 1997. Slope stability problems related to glacier shrinkage and permafrost degradation in the Alps. Eclogae Geol. Helv. 90, 407-414.

Haeberli, W., Buetler, M., Huggel, C., Friedli, T.L., Schaub, Y., Schleiss, A.J., 2016. New lakes in deglaciating high-mountain regions-opportunities and risks. Clim. Change 139, 201-214.

Haeberli, W., Huggel, C., Kääb, A., Zgraggen-Oswald, S., Polkvoj, A., Galushkin, I., Zotikov, I., Osokin, N., 2004. The Kolka-Karmadon rock/ice slide of 20 September 2002: an extraordinary event of historical dimensions in North Ossetia, Russian Caucasus. J. Glaciol. 50, 533-546.

Haeberli, W., Noetzli, J., Arenson, L., Delaloye, R., Gärtner-Roer, I., Gruber, S., Isaksen, K., Kneisel, C., Krautblatter, M., Phillips, M., 2011. Mountain permafrost: Development and challenges of a young research field. J. Glaciol. 56, 1043-1058. https://doi.org/10.3189/002214311796406121

Haeberli, W., Rickenmann, D., Zimmermann, M., 1990. Investigation of 1987 debris flows in the Swiss Alps: general concept and geophysical soundings. Hydrol. Mt. Reg. II - Artif. Reserv. WAter Slopes. IAHS Publ. np. 194 303-310.

Haeberli, W., Schaub, Y., Huggel, C., 2017a. Increasing risks related to landslides from degrading permafrost into new lakes in de-glaciating mountain ranges. Geomorphology 293, 405-417. https://doi.org/10.1016/j.geomorph.2016.02.009

Haeberli, W., Schaub, Y., Huggel, C., 2017b. Increasing risks related to landslides from degrading permafrost into new lakes in de-glaciating mountain ranges. Geomorphology 293, 405-417. https://doi.org/10.1016/j.geomorph.2016.02.009

Haque, U., Blum, P., Da Silva, P.F., Andersen, P., Pilz, J., Chalov, S.R., Malet, J.-P., Auflič, M.J., Andres, N., Poyiadji, E., 2016. Fatal landslides in Europe. Landslides 13, 1545-1554.

Haque, U., Da Silva, P.F., Devoli, G., Pilz, J., Zhao, B., Khaloua, A., Wilopo, W., Andersen, P., Lu, P., Lee, J., 2019. The human cost of global warming: Deadly landslides and their triggers (1995-2014). Sci. Total Environ. 682, 673-684.

Harris, C., 2005. Climate change, mountain permafrost degradation and geotechnical hazard, in: Global Change and Mountain Regions. An Overview of Current Knowledge. pp. 215-224.

Harris, C., Arenson, L.U., Christiansen, H.H., Etzelmüller, B., Frauenfelder, R., Gruber, S., Haeberli, W., Hauck, C., Hoelzle, M., Humlum, O., 2009. Permafrost and climate in Europe: Monitoring and modelling thermal, geomorphological and geotechnical responses. Earth-Science Rev. 92, 117171.

Harris, C., Haeberli, W., Vonder Mühll, D., King, L., 2001. Permafrost monitoring in the high mountains 
of Europe: the PACE project in its global context. Permafr. Periglac. Process. 12, 3-11.

Harris, S.A., Pedersen, D.E., 1998. Thermal regimes beneath coarse blocky materials. Permafr. Periglac. Process. 9, 107-120.

Harrison, S., Kargel, J.S., Huggel, C., Reynolds, J., Shugar, D.H., Betts, R.A., Emmer, A., Glasser, N., Haritashya, U.K., Klimeš, J., 2018. Climate change and the global pattern of moraine-dammed glacial lake outburst floods. Cryosph. 12, 1195-1209.

Hasler, A., Geertsema, M., Foord, V., Gruber, S., Noetzli, J., 2015. The influence of surface characteristics, topography and continentality on mountain permafrost in British Columbia. Cryosphere 9, 1025-1038. https://doi.org/10.5194/tc-9-1025-2015

Hétu, B., Fortin, G., Dubé, J., Boucher, D., Buffin-Bélanger, T., Gagnon, J.-P., 2017. Les conditions nivologiques et hydro-météorologiques propices au déclenchement des coulées de slush: l'exemple du Québec (Canada). Climatologie.

Hewitt, K. 1988. Catastrophic landslide deposits in the Karakoram Himalaya, Science 242. 64-67.

Hewitt, K., Clague, J.J. and Orwin F.J. 2008: Legacies of catastrophic rock slope failures in mountain landscapes Earth Sci. Rev., 87 (2008), pp. 1-38.

Hewitt, K., 2009a. Rock avalanches that travel onto glaciers and related developments, Karakoram $\begin{array}{lllll}\text { Himalaya, Inner Asia. } \quad \text { Geomorphology } & \text { 103, }\end{array}$ https://doi.org/10.1016/j.geomorph.2007.10.017

Hewitt, K. 2009b: Catastrophic rock slope failures and late Quaternary developments in the Nanga Parbat-Haramosh Massif, Upper Indus basin, northern Pakistan Quat. Sci. Rev., 28 (2009), pp. 1055-1069

Hewitt. K. 2009c: Glacially conditioned rock-slope failures and disturbance-regime landscapes, Upper Indus Basin, northern Pakistan. J. Knight, S. Harrison (Eds.), Periglacial and Paraglacial Processes and Environments, Geological Society, London (2009), pp. 235-255

Hewitt, K., Gosse, J. and Clague, J.J. 2011. Rock avalanches and the pace of late Quaternary development of river valleys in the Karakoram Himalaya. GSA Bulletin (2011) 123 (9-10): 18361850. https://doi.org/10.1130/B30341.1

Hilger, P., Hermanns, R. L., Czekirda, J., Myhra, K. S., Gosse, J. C., \& Etzelmüller, B. (2021) Permafrost as a first order control on long-term rock-slope deformation in (Sub-) Arctic Norway. Quaternary Science Reviews, 251, 106718.

Hilley, G.E., Bürgmann, R., Ferretti, A., Novali, F. and Rocca, F. 2004. Dynamics of slow-moving landslides from permanent scatterer analysis. Science 304(5679): 1952-1955. https://doi.org/10.1126/science.1098821.

Hock, R., Rasul, G., Adler, C., Cáceres, B., Gruber, S., Hirabayashi, Y., Jackson, M., Kääb, A., Kang, S., Kutuzov, S., Milner, A., Molau, U., Morin, S., Orlove, B., Steltzer, H., 2019. High Mountain Areas. In: IPCC Special Report on the Ocean and Cryosphere in a Changing Climate. Ipcc.

Hubbard, B., Heald, A., Reynolds, J.M., Quincey, D., Richardson, S.D., Luyo, M.Z., Portilla, N.S., Hambrey, M.J., 2005. Impact of a rock avalanche on a moraine-dammed proglacial lake: Laguna Safuna Alta, Cordillera Blanca, Peru. Earth Surf. Process. Landforms J. Br. Geomorphol. Res. Gr. 30, 1251-1264.

Huggel, C., Clague, J.J., Korup, O., 2012. Is climate change responsible for changing landslide activity in high mountains? Earth Surf. Process. Landforms 37, 77-91. https://doi.org/10.1002/esp.2223

Huggel, C., Gruber, S., Caplan-Auerbach, S., Wessels, R.L., Molnia, B.F., 2008. The 2005 Mt. Steller, Alaska, rock-ice avalanche: A large slope failure in cold permafrost.

Huggel, C., 2009. Recent extreme slope failures in glacial environments: effects of thermal perturbation Quat. Sci. Rev. 28, 1119-1130.

Huggel, C., Salzmann, N., Allen, S., Caplan-Auerbach, J., Fischer, L., Haeberli, W., Larsen, C., Schneider, D., Wessels, R., 2010. Recent and future warm extreme events and high-mountain slope stability. Philos. Trans. R. Soc. A Math. Phys. Eng. Sci. 368, 2435-2459.

Huggel, C., Zgraggen-Oswald, S., Haeberli, W., Kääb, A., Polkvoj, A., Galushkin, I., Evans, S.G., 2005. The 2002 rock/ice avalanche at Kolka/Karmadon, Russian Caucasus: assessment of extraordinary avalanche formation and mobility, and application of QuickBird satellite imagery. Nat. Hazards Earth Syst. Sci. 5, 173-187. https://doi.org/10.5194/nhess-5-173-2005

Hungr, O., 2007. Dynamics of rapid landslides, in: Progress in Landslide Science. Springer, pp. 47-57.

Hungr, O., Evans, S.G., 2004. Entrainment of debris in rock avalanches: An analysis of a long run-out mechanism. Bull. Geol. Soc. Am. 116, 1240-1252. https://doi.org/10.1130/B25362.1

Hungr, O., Leroueil, S. \& Picarelli, L. 2014: The Varnes classification of landslide types, an update. Landslides 11, 167-194. https://doi.org/10.1007/s10346-013-0436-y.

Huscroft, C. a, Lipovsky, P.S., Bond, J.D., 2004. Permafrost and landslide activity: Case studies from southwestern Yukon Territory. Yukon Explor. Geol. 2003 107-119.

Huscroft, C.A., Lipovsky, P., Bond, J.D., Emond, D.S., Lewis, L.L., 2003. Permafrost and landslide 
activity: Case studies from southwestern Yukon Territory. Yukon Explor. Geol. 107-119.

Hutchinson, J.N., 1968. Field meeting on the coastal landslides of Kent: 1-3 July 1966. Proc. Geol. Assoc. 79, 227-237.

IPCC, 2012: Managing the Risks of Extreme Events and Disasters to Advance Climate Change Adaptation (eds Field, C. B. et al.) (Cambridge Univ. Press, 2012).

Iribarren Anacona, P., Mackintosh, A., Norton, K.P., 2015. Hazardous processes and events from glacier and permafrost areas: lessons from the Chilean and Argentinean Andes: GLACIER AND PERMAFROST HAZARDS IN THE EXTRATROPICAL ANDES. Earth Surf. Process. Landf. 40, 221. https://doi.org/10.1002/esp.3524

Isaksen, K., Ødegård, R.S., Eiken, T., Sollid, J.L., 2000. Composition, flow and development of two tongue-shaped rock glaciers in the permafrost of Svalbard. Permafr. Periglac. Process. 11, 241257.

Iverson, R.M., 1997. The Physics of Debris Flows. Rev. Geophys. 3, 245-296.

Jia, H., Xiang, W., Krautblatter, M., 2015. Quantifying rock fatigue and decreasing compressive and tensile strength after repeated freeze-thaw cycles. Permafr. Periglac. Process. 26, 368-377.

Jomelli, V., Francou, B., 2000. Comparing the characteristics of rockfall talus and snow avalanche landforms in an Alpine environment using a new methodological approach: Massif des Ecrins, French Alps. Geomorphology 35, 181-192. https://doi.org/10.1016/S0169-555X(00)00035-0

Jones, M.K.W., Pollard, W.H., Jones, B.M., 2019. Rapid initialization of retrogressive thaw slumps in the Canadian high Arctic and their response to climate and terrain factors. Environ. Res. Lett. 14, 55006

Jorgenson, M.T., Osterkamp, T.E., 2005. Response of boreal ecosystems to varying modes of permafrost degradation. Can. J. For. Res. 35, 2100-2111.

Kääb, A., Huggel, C., Fischer, L., Guex, S., Paul, F., Roer, I., Salzmann, N., Schlaefli, S., Schmutz, K. Schneider, D., 2005. Remote sensing of glacier-and permafrost-related hazards in high mountains: an overview.

Kääb, A., Leinss, S., Gilbert, A., Bühler, Y., Gascoin, S., Evans, S.G., Bartelt, P., Berthier, E., Brun, F., Chao, W.-A., Farinotti, D., Gimbert, F., Guo, W., Huggel, C., Kargel, J.S., Leonard, G.J., Tian, L., Treichler, D., Yao, T., 2018. Massive collapse of two glaciers in western Tibet in 2016 after surgelike instability. Nat. Geosci. 11, 114-120. https://doi.org/10.1038/s41561-017-0039-7

Kenner, R., Phillips, M., Hauck, C., Hilbich, C., Mulsow, C., Bühler, Y., Stoffel, A., Buchroithner, M., 2017. New insights on permafrost genesis and conservation in talus slopes based on observations at Flüelapass, Eastern Switzerland. Geomorphology 290, 101-113.

Khanal, N.R., Hu, J.-M., Mool, P., 2015. Glacial lake outburst flood risk in the Poiqu/Bhote Koshi/Sun Koshi river basin in the Central Himalayas. Mt. Res. Dev. 35, 351-364.

Khomutov, A., Leibman, M., 2014. Assessment of landslide hazards in a typical tundra of Central Yamal, Russia, in: Landslides in Cold Regions in the Context of Climate Change. Springer, pp. 271-290.

Kjartansson, G. 1967. The Steinsholtshlaup, Central-South-Iceland, on January 15th 1967. Jökull 17. 249-262.

Kjekstad, O., Highland, L., 2009. Economic and Social Impacts of Landslides. Landslides - Disaster Risk Reduct. 573-587. https://doi.org/10.1007/978-3-540-69970-5

Kokelj, S.V., Jorgenson, M.T., 2013. Advances in thermokarst research. Permafr. Periglac. Process. $24,108-119$.

Kokelj, S. V., Lacelle, D., Lantz, T.C., Tunnicliffe, J., Malone, L., Clark, I.D., Chin, K.S., 2013. Thawing of massive ground ice in mega slumps drives increases in stream sediment and solute flux across a range of watershed scales. J. Geophys. Res. Earth Surf. 118, 681-692. https://doi.org/10.1002/jgrf.20063

Kokelj, S. V, Tunnicliffe, J., Lacelle, D., Lantz, T.C., Chin, K.S., Fraser, R., 2015. Increased precipitation drives mega slump development and destabilization of ice-rich permafrost terrain, northwestern Canada. Glob. Planet. Change 129, 56-68.

Korup, O. (2006). Effects of large deep-seated landslides on hillslope morphology, western Southern Alps, New Zealand. Journal of Geophysical Research, 111, F01018.

Korup, O., Tweed, F., 2007. Ice, moraine, and landslide dams in mountainous terrain. Quat. Sci. Rev. 26, 3406-3422.

Kos, A., Amann, F., Strozzi, T., Delaloye, R., von Ruette, J., Springman, S., 2016. Contemporary glacier retreat triggers a rapid landslide response, Great Aletsch Glacier, Switzerland. Geophys. Res. Lett. 43, $12-466$.

Krautblatter, M., Funk, D., Günzel, F.K., 2013a. Why permafrost rocks become unstable: a rock-icemechanical model in time and space. Earth Surf. Process. Landforms 38, 876-887.

Krautblatter, M., Funk, D., Günzel, F.K., 2013b. Why permafrost rocks become unstable: A rock-icemechanical model in time and space. Earth Surf. Process. Landforms 38, 876-887. 
https://doi.org/10.1002/esp.3374

Kuhn, D., Redfield, T.F., Hermanns, R.L., Fuchs, M., Torizin, J. \& Balzer, D. 2019: Anatomy of a megarock slide at Forkastningsfjellet, Spitsbergen and its implications for landslide hazard and risk considerations. Norwegian Journal of Geology 99, 1-21. https://dx.doi.org/10.17850/njg99-1-03.

Kuhn, D., Redfield, T.F., Hermanns, R.L., Fuchs, M., Torizin, J. \& Balzer, D. 2021: Forkastningsfjellet Rock Slide, Spitsbergen: State of Activity in a Changing Climate. In: V. Vilímek et al. (eds.), Understanding and Reducing Landslide Disaster Risk, ICL Contribution to Landslide Disaster Risk Reduction, https://doi.org/10.1007/978-3-030-60319-9 21

Kummert, M., Delaloye, R., \& Braillard, L. (2018). Erosion and sediment transfer processes at the front of rapidly moving rock glaciers: Systematic observations with automatic cameras in the western Swiss Alps. Permafrost and Periglacial Processes, 29(1), 21-33.

Lacelle, D., Bjornson, J., Lauriol, B., 2010. Climatic and geomorphic factors affecting contemporary (1950-2004) activity of retrogressive thaw slumps on the Aklavik plateau, Richardson mountains, NWT, Canada. Permafr. Periglac. Process. 21, 1-15. https://doi.org/10.1002/ppp.666

Lafrenière, M.J., Lamoureux, S.F., 2019. Effects of changing permafrost conditions on hydrological processes and fluvial fluxes. Earth-science Rev. 191, 212-223.

Lamoureux, S.F., Lafrenière, M.J., 2009. Fluvial impact of extensive active layer detachments, Cape Bounty, Melville Island, Canada. Arctic, Antarct. Alp. Res. 41, 59-68.

Lane, S.N., Bakker, M., Gabbud, C., Micheletti, N., Saugy, J.-N., 2017. Sediment export, transient landscape response and catchment-scale connectivity following rapid climate warming and Alpine glacier recession. Geomorphology 277, 210-227.

Lantuit, H., Overduin, P.P., Couture, N., Wetterich, S., Aré, F., Atkinson, D., Brown, J., Cherkashov, G., Drozdov, D., Forbes, D.L., 2012. The Arctic coastal dynamics database: a new classification scheme and statistics on Arctic permafrost coastlines. Estuaries and Coasts 35, 383-400.

Lantuit, H., Pollard, W.H., 2008. Fifty years of coastal erosion and retrogressive thaw slump activity on Herschel Island, southern Beaufort Sea, Yukon Territory, Canada. Geomorphology 95, 84-102. https://doi.org/10.1016/j.geomorph.2006.07.040

Lantuit, H., Pollard, W.H., Couture, N., Fritz, M., Schirrmeister, L., Meyer, H., Hubberten, H.W., 2012. Modern and Late Holocene Retrogressive Thaw Slump Activity on the Yukon Coastal Plain and Herschel Island, Yukon Territory, Canada. Permafr. Periglac. Process. 23, 39-51. https://doi.org/10.1002/ppp.1731

Larocque, S.J., Hétu, B., Filion, L., 2001. Geomorphic and dendroecological impacts of slushflows in central gaspé peninsula (québec, canada). Geogr. Ann. Ser. Phys. Geogr. 83, 191-201. https://doi.org/10.1111/j.0435-3676.2001.00154.x

Leibman, M.O., 1995. Cryogenic landslides on the Yamal Peninsula, Russia: preliminary observations. Permafr. Periglac. Process. 6, 259-264.

Lewin, J., Warburton, J., 1994. Debris Flows in an Alpine Environment. Geography 79, 98-107.

Lewkowicz, A.G., 2007. Dynamics of active-layer detachment failures, Fosheim peninsula, Ellesmere Island, Nunavut, Canada. Permafr. Periglac. Process. 18, 89-103.

Lewkowicz, A.G., 1990. Morphology, frequency and magnitude of active-layer detachment slides, Fosheim Peninsula, Ellesmere Island, N.W.T., in: Permafrost-Canada, Proceedings of the Fifth Canadian Permafrost Conference, National Research Council of Canada. pp. 111-118.

Lewkowicz, A.G., Dixon, J.C., Abrahams, A.D., 1992. Factors influencing the distribution and initiation of active-layer detachment slides on Ellesmere Island, Arctic Canada.

Lewkowicz, A.G., Harris, C., 2005a. Morphology and geotechnique of active-layer detachment failures in discontinuous and continuous permafrost, northern Canada. Geomorphology 69, 275-297. https://doi.org/10.1016/j.geomorph.2005.01.011

Lewkowicz, A.G, Harris, C., 2005b. Frequency and magnitude of active-layer detachment failures in discontinuous and continuous permafrost, northern Canada. Permafr. Periglac. Process. 16, 115130.

Lewkowicz, A.G., Kokelj, S. V, 2002. Slope sediment yield in arid lowland continuous permafrost environments, Canadian Arctic Archipelago. Catena 46, 261-283.

Lewkowicz, A.G., Way, R.G., 2019. Extremes of summer climate trigger thousands of thermokarst landslides in a High Arctic environment. Nat. Commun. 10, 1-11. https://doi.org/10.1038/s41467019-09314-7

Luckman, B.H., 1992. Debris flows and snow avalanches landforms in the Lairig Ghru, Cairngorm Mountains, Scotland. Geogr. Ann. Ser. -Phys. Geogr. 74, 109-121.

Lugon, R., \& Stoffel, M. (2010). Rock-glacier dynamics and magnitude-frequency relations of debris flows in a high-elevation watershed: Ritigraben, Swiss Alps. Global and Planetary Change, 73(34), 202-210.

Lukas, S., Nicholson, L.I., Ross, F.H., Humlum, O., 2005. Formation, meltout processes and landscape 
alteration of high-Arctic ice-cored moraines-Examples from Nordenskiold Land, central Spitsbergen. Polar Geogr. 29, 157-187.

Luo, J., Niu, F., Lin, Z., Liu, M., Yin, G., 2019. Recent acceleration of thaw slumping in permafrost terrain of Qinghai-Tibet Plateau: An example from the Beiluhe Region. Geomorphology 341, 79-85.

Lutz, A., Immerzeel, W.W., Bajracharya, S.R., Litt, M., Shrestha, A.B., 2016. Impacts of climate change on the cryosphere, hydrological regimes and glacial lakes of the Hindu Kush Himalayas: a review of current knowledge. ICIMOD.

Magnin, F., Etzelmüller, B., Westermann, S., Isaksen, K., Hilger, P., Hermanns, R.L., 2019. Permafrost distribution in steep slopes in Norway: measurements, statistical modelling and geomorphological implication. Earth Surf. Dyn. Discuss. 1-35. https://doi.org/10.5194/esurf-2018-90

Magnin, F., Haeberli, W., Linsbauer, A., Deline, P., Ravanel, L., 2020. Estimating glacier-bed overdeepenings as possible sites of future lakes in the de-glaciating Mont Blanc massif (Western European Alps). Geomorphology 350, 106913. https://doi.org/10.1016/j.geomorph.2019.106913

Marcer, M., Ringsø, Nielsen, S., Ribeyre, C., Kummert, M., Duvillard, P. A., Schoeneich, P., ... \& Genuite, K. (2020). Investigating the slope failures at the Lou rock glacier front, French Alps. Permafrost and Periglacial Processes, 31(1), 15-30.

Masson-Delmotte, V., Kageyama, M., Braconnot, P., Charbit, S., Krinner, G., Ritz, C., Guilyardi, E., Jouzel, J., Abe-Ouchi, A., Crucifix, M., 2006. Past and future polar amplification of climate change: climate model intercomparisons and ice-core constraints. Clim. Dyn. 26, 513-529.

Masyagina, O. V, Evgrafova, S.Y., Bugaenko, T.N., Kholodilova, V. V, Krivobokov, L. V, Korets, M.A., Wagner, D., 2019. Permafrost landslides promote soil CO2 emission and hinder C accumulation. Sci. Total Environ. 657, 351-364.

Matsuoka, N., Murton, J., 2008. Frost weathering: recent advances and future directions. Permafr. Periglac. Process. 19, 195-210.

Mège, D. and Bourgeois, O. 2011: Equatorial glaciations on Mars revealed by gravitational collapse of Valles Marineris wallslopes Earth Planet. Sci. Lett., 310 (2011), pp. 182-191.

McColl, S.T., 2012. Paraglacial rock-slope stability. Geomorphology 153, 1-16.

McColl, S.T., Davies, T.R.H., 2013. Large ice-contact slope movements: glacial buttressing, deformation and erosion. Earth Surf. Process. Landforms 38, 1102-1115.

McColl, S.T., Draebing, D., 2019. Rock slope instability in the proglacial zone: State of the Art, in: Geomorphology of Proglacial Systems. Springer, pp. 119-141.

McSaveney, M., 2002: Recent rock falls and rock avalanches on Mount Cook National Park, New Zeland. In: Evans, S.G., DeGraff, J.V. (Eds), Catastrophic Landslides: Effects, Occurrence, and Mechanisms, Reviews in Engineering Geology, vol. 15, pp. 35-70.

Mercier, D., Coquin, J., Feuillet, T., Decaulne, A., Cossart, E., Jónsson, H.P., Sæmundsson, P., 2017. Are Icelandic rock-slope failures paraglacial? Age evaluation of seventeen rock-slope failures in the Skagafjörður area, based on geomorphological stacking, radiocarbon dating and tephrochronology. Geomorphology 296, 45-58. https://doi.org/10.1016/j.geomorph.2017.08.011

Monnier, S., Kinnard, C., 2015. Internal structure and composition of a rock glacier in the dry Andes, inferred from ground-penetrating radar data and its artefacts. Permafr. Periglac. Process. 26, 335346.

Mool, P.K., Maskey, P.R., Koirala, A., Joshi, S.P., Lizong, W., Shrestha, A.B., Eriksson, M., Gurung, B., Pokharel, B., Khanal, N.R., 2011. Glacial lakes and glacial lake outburst floods in Nepal. The World Bank.

Moreiras, S., Lisboa, M.S., Mastrantonio, L., 2012. The role of snow melting upon landslides in the central Argentinean Andes: LANDSLIDE ACTIVITY IN THE ACONCAGUA PARK, ARGENTINA. Earth Surf. Process. Landf. 37, 1106-1119. https://doi.org/10.1002/esp.3239

Morino, C., Conway, S.J., Sæmundsson, P., Helgason, J.K., Hillier, J., Butcher, F.E.G., Balme, M.R., Jordan, C., Argles, T., 2019. Molards as an indicator of permafrost degradation and landslide processes. Earth Planet. Sci. Lett. 516. https://doi.org/10.1016/j.epsl.2019.03.040

Mourey, J., Marcuzzi, M., Ravanel, L., Pallandre, F., 2019. Effects of climate change on high Alpine mountain environments: Evolution of mountaineering routes in the Mont Blanc massif (Western Alps) over half a century. Arctic, Antarct. Alp. Res. 51, 176-189.

Muller, S.W., 1945. ... Permafrost, Or Permanently Frozen Ground: And Related Engineering Problems. Army map service, US Army.

Murton, J.B., 2001. Thermokarst sediments and sedimentary structures, Tuktoyaktuk Coastlands, western Arctic Canada. Glob. Planet. Change 28, 175-192. https://doi.org/10.1016/S09218181(00)00072-2

Murton, J.B., Edwards, M.E., Lozhkin, A. V., Anderson, P.M., Savvinov, G.N., Bakulina, N., Bondarenko, O. V., Cherepanova, M. V., Danilov, P.P., Boeskorov, V., Goslar, T., Grigoriev, S., Gubin, S. V., Korzun, J.A., Lupachev, A. V., Tikhonov, A., Tsygankova, V.I., Vasilieva, G. V., Zanina, O.G., 
2017. Preliminary paleoenvironmental analysis of permafrost deposits at Batagaika megaslump, Yana Uplands, northeast Siberia. Quat. Res. (United States) 87, 314-330. https://doi.org/10.1017/qua.2016.15

Murton, J.B., Peterson, R., Ozouf, J.-C., 2006. Bedrock fracture by ice segregation in cold regions. Science (80-. ). 314, 1127-1129.

Nyberg, R., 1989. Observations of Slushflows and Their Geomorphological Effects in the Swedish Mountain Area. Geogr. Ann. Ser. Phys. Geogr. 71, 185-198.

Oliva, M., Ruiz-Fernández, J., 2015. Coupling patterns between para-glacial and permafrost degradation responses in Antarctica. Earth Surf. Process. Landforms 40, 1227-1238.

Oppikofer, T., Saintot, A., Hermanns, R., Böhme, M., Scheiber, T., Gosse, J., and Dreiås, G., 2017, From incipient slope instability through slope deformation to catastrophic failure-Different stages of failure development on the Ivasnasen and Vollan rock slopes (western Norway): Geomorphology, v. 289, p. 96-116.

Oppikofer, T., Hermanns, R.L., Jakobsen, V.U., Böhme, M., Nicolet, P., Penna, I., 2020. Forecasting dam height and stability of dams formed by rock slope failures in Norway. Nat. Hazards Earth Syst. Sci. Discuss. 1-24.

Osterkamp, T.E., Jorgenson, M.T., Schuur, E.A.G., Shur, Y.L., Kanevskiy, M.Z., Vogel, J.G., Tumskoy, V.E., 2009. Physical and ecological changes associated with warming permafrost and thermokarst in interior Alaska. Permafr. Periglac. Process. 20, 235-256.

Pacione, M. 1999: Applied Geography: Principles and Practice. Routledge, London, 664 pp.

Panda, S.K., Marchenko, S.S., Romanovsky, V.E., 2014. High-resolution permafrost modeling in Denali National Park and Preserve. Nat. Resour. Techn. Rep 1-44.

Pánek, T., Smolková, V., Hradecký, J.,Baroň, I. and Šilhán, K. 2013: Holocene reactivations of catastrophic complex flow-like landslides in the Flysch Carpathians (Czech Republic/Slovakia) Quat. Res., 80 (2013), pp. 33-46.

Pánek, T. and Klimeš, J. 2016: Temporal behavior of deep-seated gravitational slope deformations: A review. Earth-Science Reviews. Volume 156, May 2016, P. 14-38.

Pastick, N.J., Jorgenson, M.T., Wylie, B.K., Nield, S.J., Johnson, K.D., Finley, A.O., 2015. Distribution of near-surface permafrost in Alaska: Estimates of present and future conditions. Remote Sens. Environ. 168, 301-315.

Patton, A.I., Rathburn, S.L., Capps, D.M., 2019a. Landslide response to climate change in permafrost regions. Geomorphology 340, 116-128. https://doi.org/10.1016/j.geomorph.2019.04.029

Patton, A.I., Rathburn, S.L., Capps, D.M., 2019b. Landslide response to climate change in permafrost regions. Geomorphology 340, 116-128. https://doi.org/10.1016/j.geomorph.2019.04.029

Pautler, B.G., Austin, J., Otto, A., Stewart, K., Lamoureux, S.F., Simpson, M.J., 2010. Biomarker assessment of organic matter sources and degradation in Canadian High Arctic littoral sediments. Biogeochemistry 100, 75-87.

Pedrazzini, A., Jaboyedoff, M.; Loye, A. and Derron, M.H. 2013: From deep seated slope deformation to rock avalanche: destabilization and transportation models of the Sierre landslide (Switzerland) Tectonophysics, 605 (2013), pp. 149-168

Pérez-Guillén, C., Tsunematsu, K., Nishimura, K., Issler, D., 2019. Seismic location and tracking of snow avalanches and slush flows on Mt. Fuji, Japan. Earth Surf. Dyn. 7, 989-1007. https://doi.org/10.5194/esurf-7-989-2019

Petley, D., 2012. Global patterns of loss of life from landslides. Geology 40, 927-930. https://doi.org/10.1130/G33217.1

Petrakov, D.A., Chernomorets, S.S., Evans, S.G., Tutubalina, O.V., 2008. Catastrophic glacial multiphase mass movements: a special type of glacial hazard. Adv. Geosci. 14, 211-218. https://doi.org/10.5194/adgeo-14-211-2008

Péwé, R., Brown, T., 1973. Distribution of permafrost in North America and its relationship to the environment: a review, 1963-1973, in: Permafrost: North American Contribution [to The] Second International Conference. National Academies, p. 71.

Péwé, T.L., 1983. Alpine permafrost in the contiguous United States: a review. Arct. Alp. Res. 15, 145156.

Pirulli, M., 2009. The Thurwieser rock avalanche (Italian Alps): Description and dynamic analysis. Eng. Geol. 109, 80-92. https://doi.org/10.1016/j.enggeo.2008.10.007

Post, A.S. 1965: Alaskan Glaciers: recent observations in respect to the earthquake-advance theory. Science 148. 366-368.

Price, M.F., Byers, A.C., Friend, D.A., Kohler, T., Price, L.W. (Eds.), 2019. 4. Snow, Ice, Avalanches, and Glaciers, in: Mountain Geography. University of California Press, pp. 85-126. https://doi.org/10.1525/9780520956971-008

Prick, A., 2003. Frost weathering and rock fall in an arctic environment, Longyearbyen, Svalbard, in: 
Pröbstl-Haider, U., Dabrowska, K., Haider, W., 2016. Risk perception and preferences of mountain tourists in light of glacial retreat and permafrost degradation in the Austrian Alps. J. Outdoor Recreat. Tour. 13, 66-78.

Pudasaini, S.P., Krautblatter, M., 2014. A two-phase mechanical model for rock-ice avalanches. J. Geophys. Res. Earth Surf. 119, 2272-2290. https://doi.org/10.1002/2014JF003183

Racine, C., Jandt, R., Meyers, C., Dennis, J., 2004. Tundra fire and vegetation change along a hillslope on the Seward Peninsula, Alaska, USA. Arctic, Antarct. Alp. Res. 36, 1-10.

Ravanel, L., Deline, P., 2008. La face ouest des Drus (massif du Mont-Blanc): évolution de l'instabilité d'une paroi rocheuse dans la haute montagne alpine depuis la fin du petit âge glaciaire. Géomorphologie Reli. Process. Environ. 14, 261-272.

Ravanel, L., Magnin, F., Deline, P., 2017. Impacts of the 2003 and 2015 summer heatwaves on permafrost-affected rock-walls in the Mont Blanc massif. Sci. Total Environ. 609, 132-143. https://doi.org/10.1016/j.scitotenv.2017.07.055

Rebetez, M., Lugon, R., Baeriswyl, P.-A., 1997. Climatic change and debris flows in high mountain regions: the case study of the Ritigraben torrent (Swiss Alps), in: Climatic Change at High Elevation Sites. Springer, pp. 139-157.

Reznichenko, N.V., Davies, T.R.H., Alexander, D.J., 2011. Effects of rock avalanches on glacier behaviour and moraine formation. Geomorphology 132, 327-338. https://doi.org/10.1016/j.geomorph.2011.05.019

Richardson, S.D., Reynolds, J.M., 2000. Degradation of ice-cored moraine dams: implications for hazard development. IAHS Publ. 187-198.

Robinson, T.R., Davies, T.R.H., Reznichenko, N.V., De Pascale, G.P., 2014. The extremely long-runout Komansu rock avalanche in the Trans Alai range, Pamir Mountains, southern Kyrgyzstan. Landslides 1-13. https://doi.org/10.1007/s10346-014-0492-y

Romanovsky, V.E., Smith, S.L., Christiansen, H.H., 2010. Permafrost thermal state in the polar Northern Hemisphere during the international polar year 2007-2009: a synthesis. Permafr. Periglac. Process. 21, 106-116.

Sæmundsson, P., Morino, C., Helgason, J.K., Conway, S.J., Pétursson, H.G., 2018. The triggering factors of the Móafellshyrna debris slide in northern Iceland: Intense precipitation, earthquake activity and thawing of mountain permafrost. Sci. Total Environ. 621, 1163-1175. https://doi.org/10.1016/j.scitotenv.2017.10.111

Saroli, M., Stramondo, S., Moro, M. and Doumaz, F. (2005). Movements detection of deep seated gravitational slope deformations by means of InSAR data and photogeological interpretation: Northern Sicily case study. Terra Nova, 17, 35-43.

Sattler, K., Keiler, M., Zischg, A., Schrott, L., 2011. On the connection between debris flow activity and permafrost degradation: a case study from the Schnalstal, South Tyrolean Alps, Italy. Permafr. Periglac. Process. 22, 254-265.

Schild, A., 2008. ICIMOD's position on climate change and mountain systems. Mt. Res. Dev. 28, 328331.

Schleier, M., Hermanns, R.L., Rohn, J., Gosse, J.C., 2015. Diagnostic characteristics and paleodynamics of supraglacial rock avalanches, Innerdalen, Western Norway. Geomorphology 245, 23-39. https://doi.org/10.1016/j.geomorph.2015.04.033

Schleier, M., Hermanns, R. L., Krieger, I., Oppikofer, T., Eiken, T., Rønning, J. S. and Rohn, J., 2016, Gravitational reactivation of a pre-existing post-Caledonian fault system: the deep-seated gravitational slope deformation at Middagstinden, western Norway: Norwegian Journal of Geology, v. 96, p. 1-24.

Schlögel, R., Torgoev, I., De Marneffe, C., Havenith, H., 2011. Evidence of a changing size-frequency distribution of landslides in the Kyrgyz Tien Shan, Central Asia. Earth Surf. Process. Landforms 36, 1658-1669.

Schneider, D., Huggel, C., Haeberli, W., Kaitna, R., 2011. Unraveling driving factors for large rock-ice avalanche mobility: UNRAVELING DRIVING FACTORS FOR LARGE ROCK-ICE AVALANCHE MOBILITY. Earth Surf. Process. Landf. 36, 1948-1966. https://doi.org/10.1002/esp.2218

Schoeneich, P., Dall'Amico, M., Deline, P., Zischg, A., 2011. Hazards related to permafrost and to permafrost degradation. PermaNET Proj. state-of-the-art Rep. 6.

Schuur, E.A.G., Bockheim, J., Canadell, J.G., Euskirchen, E., Field, C.B., Goryachkin, S. V, Hagemann, S., Kuhry, P., Lafleur, P.M., Lee, H., 2008. Vulnerability of permafrost carbon to climate change: Implications for the global carbon cycle. Bioscience 58, 701-714.

Schuur, E.A.G., Vogel, J.G., Crummer, K.G., Lee, H., Sickman, J.O., Osterkamp, T.E., 2009. The effect of permafrost thaw on old carbon release and net carbon exchange from tundra. Nature 459, 556559. 
Schwanghart, W., Worni, R., Huggel, C., Stoffel, M., Korup, O., 2016. Uncertainty in the Himalayan energy-water nexus: Estimating regional exposure to glacial lake outburst floods. Environ. Res. Lett. 11, 74005.

Screen, J.A., Deser, C., Simmonds, I., 2012. Local and remote controls on observed Arctic warming Geophys. Res. Lett. 39.

Segal, R.A., Lantz, T.C., Kokelj, S. V., 2016. Acceleration of thaw slump activity in glaciated landscapes of the Western Canadian Arctic. Environ. Res. Lett. 11. https://doi.org/10.1088/17489326/11/3/034025

Shrestha, A.B., Eriksson, M., Mool, P., Ghimire, P., Mishra, B., Khanal, N.R., 2010. Glacial lake outburst flood risk assessment of Sun Koshi basin, Nepal. Geomatics, Nat. Hazards Risk 1, 157-169.

Shreve, R.L., 1966. Sherman Landslide, Alaska. Science 154, 1639-1643. https://doi.org/10.1126/science.154.3757.1639

Shugar, D.H., Clague, J.J., 2011. The sedimentology and geomorphology of rock avalanche deposits on glaciers: Rock avalanches on glaciers. Sedimentology 58, 1762-1783. https://doi.org/10.1111/j.1365-3091.2011.01238.x

Shulmeister, J., Davies, T.R., Evans, D.J.A., Hyatt, O.M., Tovar, D.S., 2009. Catastrophic landslides, glacier behaviour and moraine formation - A view from an active plate margin. Quat. Sci. Rev. 28, 1085-1096. https://doi.org/10.1016/j.quascirev.2008.11.015

Sidle, R.C., Ochiai, H., 2006. Natural factors influencing landslides. Landslides Process. Predict. L. Use $18,41-119$.

Slater, A.G., Lawrence, D.M., 2013. Diagnosing present and future permafrost from climate models. J. Clim. 26, 5608-5623.

Smith, W.D., Dunning, S.A., Brough, S., Ross, N., Telling, J., 2020. GERALDINE (Google Earth Engine supRaglAciaL Debris INput dEtector): a new tool for identifying and monitoring supraglacial landslide inputs. Earth Surf. Dyn. 8, 1053-1065. https://doi.org/10.5194/esurf-8-1053-2020

Sosio, R., Crosta, G.B., Hungr, O., 2008. Complete dynamic modeling calibration for the Thurwieser rock avalanche (Italian Central Alps). Eng. Geol. 100, 11-26. https://doi.org/10.1016/j.enggeo.2008.02.012

Sosio, R., Crosta, G.B., Chen, J.H., Hungr, O., 2012. Modelling rock avalanche propagation onto glaciers. Quat. Sci. Rev. 47, 23-40. https://doi.org/10.1016/j.quascirev.2012.05.010

Stearns, S.R., 1966. Permafrost (perennially frozen ground).

Stoffel, M., Huggel, C., 2012. Effects of climate change on mass movements in mountain environments. Prog. Phys. Geogr. 36, 421-439.

Strom, A., Korup, O., 2006. Extremely large rockslides and rock avalanches in the Tien Shan Mountains Kyrgyzstan. Landslides 3, 125-136. https://doi.org/10.1007/s10346-005-0027-7

Subcommittee, P., 1988. Glossary of permafrost and related ground-ice terms. Assoc. Comm. Geotech. Res. Natl. Res. Counc. Canada, Ottawa 156.

Svennevig, K., Solgaard, A.M., Salehi, S., Dahl-Jensen, T., Merryman Boncori, J.P., Larsen, T.B., Voss, P.H., 2019. A multidisciplinary approach to landslide monitoring in the Arctic: Case study of the March 2018 ML 1.9 seismic event near the Karrat 2017 landslide. Geol. Surv. Denmark Greenl. Bull. 43. https://doi.org/10.34194/GEUSB-201943-02-08

Tarnocai, C., Canadell, J.G., Schuur, E.A.G., Kuhry, P., Mazhitova, G., Zimov, S., 2009. Soil organic carbon pools in the northern circumpolar permafrost region. Global Biogeochem. Cycles 23.

Teshebaeva, K., Echtler, H., Bookhagen, B. and Strecker, M. 2019 Deep-seated gravitational slope deformation (DSGSD) and slow-moving landslides in the southern Tien Shan Mountains: new insights from InSAR, tectonic and geomorphic analysis. Earth Surf. Process. Landforms 44, 23332348.

Thomas, H.R., Cleall, P., Li, Y.-C., Harris, C., Kern-Luetschg, M., 2009. Modelling of cryogenic processes in permafrost and seasonally frozen soils. Géotechnique 59, 173-184. https://doi.org/10.1680/geot.2009.59.3.173

Tian, L., Yao, T., Gao, Y., Thompson, L., Mosley-Thompson, E., Muhammad, S., Zong, J., Wang, C., Jin, S., Li, Z., 2017. Two glaciers collapse in western Tibet. J. Glaciol. 63, 194-197. https://doi.org/10.1017/jog.2016.122

Tricart, J., 1956. Etude expérimentale du problème de la gélivation. Biul. Peryglac. 4, 285-318.

Turetsky, M.R., Abbott, B.W., Jones, M.C., Anthony, K.W., Olefeldt, D., Schuur, E.A.G., Koven, C., McGuire, A.D., Grosse, G., Kuhry, P., 2019. Permafrost collapse is accelerating carbon release.

Uhlmann, M., Korup, O., Huggel, C., Fischer, L., Kargel, J.S., 2013. Supra-glacial deposition and flux of catastrophic rock-slope failure debris, south-central Alaska. Earth Surf. Process. Landforms 38, 675-682.

UNDHA, 1992. Internationally agreed glossary of basic terms related to disaster management. UNDHA (United Nations Dep. Humanit. Aff. Geneva. 
Vadakkedath, V., Zawadzki, J., Przeździecki, K., 2020. Multisensory satellite observations of the expansion of the Batagaika crater and succession of vegetation in its interior from 1991 to 2018. Environ. Earth Sci. 79, 150. https://doi.org/10.1007/s12665-020-8895-7

Van Vliet-Lanoë, B., Fox, C.A., 2018. Frost action, in: Interpretation of Micromorphological Features of Soils and Regoliths. Elsevier, pp. 575-603.

Varnes, D. J., Radbruch-Hall, D., Varnes, K. L., Smith, W. K. and Savage, W. Z. (1990). Measurement of Ridge-spreading Movements (Sackungen) at Bald Eagle Mountain, Lake County, Colorado, 1975-1989. US Geological Survey, Open File Report 90-543.

Varnes, D.J., 1984. Landslide hazard zonation: a rewiew od principles and practise. Nat. Hazard Ser. https://doi.org/10.1007/BF02594720

Varnes, D.J., 1978. Slope Movement Types and Processes. Transp. Res. Board Spec. Rep. 11-33. https://doi.org/ln Special report 176: Landslides: Analysis and Control, Transportation Research Board, Washington, D.C.

Veh, G., Korup, O., von Specht, S., Roessner, S., Walz, A., 2019. Unchanged frequency of morainedammed glacial lake outburst floods in the Himalaya. Nat. Clim. Chang. 9, 379-383.

Verdonen, M., Berner, L.T., Forbes, B.C., Kumpula, T., 2020. Periglacial vegetation dynamics in Arctic Russia: decadal analysis of tundra regeneration on landslides with time series satellite imagery. Environ. Res. Lett. 15, 105020.

Vieira, G., López-Martínez, J., Serrano, E., Ramos, M., Gruber, S., Hauck, C., Blanco, J.J., 2008. Geomorphological observations of permafrost and ground-ice degradation on Deception and Livingston Islands, Maritime Antarctica.

Walls, M., Hvidberg, M., Kleist, M., Knudsen, P., Mørch, P., Egede, P., ... \& Watanabe, T. (2020). Hydrological instability and archaeological impact in Northwest Greenland: Sudden mass movement events signal new concerns for circumpolar archaeology. Quaternary Science Reviews, 248, 106600 .

Washburn, A.L., 1980. Permafrost features as evidence of climatic change. Earth-Science Rev. 15, 327402.

Wegmann, M., Gudmundsson, G.H., Haeberli, W., 1998. Permafrost changes in rock walls and the retreat of alpine glaciers: a thermal modelling approach. Permafr. Periglac. Process. 9, 23-33. https://doi.org/10.1002/(SICl)1099-1530(199801/03)9:1<23::AID-PPP274>3.0.CO;2-Y

Westermann, S., Peter, M., Langer, M., Schwamborn, G., Schirrmeister, L., Etzelmüller, B., Boike, J., 2017. Transient modeling of the ground thermal conditions using satellite data in the Lena River delta, Siberia. Cryosph. 11, 1441-1463.

Westoby, M.J., Glasser, N.F., Hambrey, M.J., Brasington, J., Reynolds, J.M., Hassan, M.A.A.M., 2014 Reconstructing historic Glacial Lake Outburst Floods through numerical modelling and geomorphological assessment: Extreme events in the Himalaya. Earth Surf. Process. Landforms 39, 1675-1692.

Wood, J.L., Harrison, S., Reinhardt, L., Taylor, F.E., 2020. Landslide databases for climate change detection and attribution. Geomorphology 355, 107061.

Woods, G.C., Simpson, M.J., Pautler, B.G., Lamoureux, S.F., Lafrenière, M.J., Simpson, A.J., 2011. Evidence for the enhanced lability of dissolved organic matter following permafrost slope disturbance in the Canadian High Arctic. Geochim. Cosmochim. Acta 75, 7226-7241.

Yamasaki, S., Nagata, H., Kawaguchi, T., 2014. Long-traveling landslides in deep snow conditions induced by the 2011 Nagano Prefecture earthquake, Japan. Landslides 11, 605-613. https://doi.org/10.1007/s10346-013-0419-z

Yu, G.-A., Yao, W., Huang, H.Q., Liu, Z., 2020. Debris flows originating in the mountain cryosphere under a changing climate: A review. Prog. Phys. Geogr. Earth Environ. 0309133320961705.

Zischinsky, U. (1966). On the deformation of high slopes. In Proceedings of the First Conference of the International Society for Rock Mechanics, Vol. 2, pp. 179-185.

Zimmermann, M., 1990. Debris flows 1987 in Switzerland: geomorphological and meteorological aspects. Hydrol. Mt. Reg. II - Artif. Reserv. Water Slopes 1, 387-394.

Zimmermann, M., Haeberli, W., 1992. Climatic change and debris flow activity in high-mountain areas. A case study in the Swiss Alps. Catena. Suppl. 59-72.

Zongxing, L., Qi, F., Wang, Q.J., Song, Y., Aifang, C., Jianguo, L., 2016. Contribution from frozen soil meltwater to runoff in an in-land river basin under water scarcity by isotopic tracing in northwestern China. Glob. Planet. Change 136, 41-51.

Zou, D., Zhao, L., Yu, S., Chen, J., Hu, G., Wu, T., Wu, J., Xie, C., Wu, X., Pang, Q., 2017. A new map of permafrost distribution on the Tibetan Plateau. Cryosph. 11, 2527. 